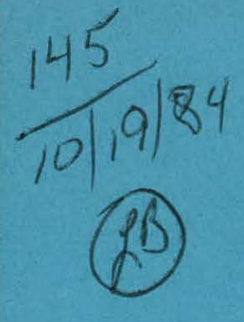

\title{
ENTHALPY STUDIES
}

Final Report

By

P. M. Mathias

F.P. Stein

May 1984

Work Performed Under Contract No. AC05-780R03054

Air Products and Chemicals, Inc.

Allentown, Pennsylvania

and

Lehigh University

Bethlehem, Pennsylvania

and

International Coal Refining Company

Allentown, Pennsylvania

Technical Information Center

Office of Scientific and Technical Information United States Department of Energy 


\section{DISCLAIMER}

This report was prepared as an account of work sponsored by an agency of the United States Government. Neither the United States Government nor any agency Thereof, nor any of their employees, makes any warranty, express or implied, or assumes any legal liability or responsibility for the accuracy, completeness, or usefulness of any information, apparatus, product, or process disclosed, or represents that its use would not infringe privately owned rights. Reference herein to any specific commercial product, process, or service by trade name, trademark, manufacturer, or otherwise does not necessarily constitute or imply its endorsement, recommendation, or favoring by the United States Government or any agency thereof. The views and opinions of authors expressed herein do not necessarily state or reflect those of the United States Government or any agency thereof. 


\section{DISCLAIMER}

Portions of this document may be illegible in electronic image products. Images are produced from the best available original document. 


\title{
DISCLAIMER
}

\begin{abstract}
This report was prepared as an account of work sponsored by an agency of the United States Government. Neither the United States Government nor any agency thereof, nor any of their employees, makes any warranty, express or implied, or assumes any legal liability or responsibility for the accuracy, completeness, or usefulness of any information, apparatus, product, or process disclosed, or represents that its use would not infringe privately owned rights. Reference herein to any specific commercial product, process, or service by trade name, trademark, manufacturer, or otherwise does not necessarily constitute or imply its endorsement, recommendation, or favoring by the United States Government or any agency thereof. The views and opinions of authors expressed herein do not necessarily state or reflect those of the United States Government or any agency thereof.
\end{abstract}

This report has been reproduced directly from the best available copy.

Available from the National Technical Information Service, U. S. Department of Commerce, Springfield, Virginia 22161.

Price: Printed Copy A04

Microfiche A01

Codes are used for pricing all publications. The code is determiner by the number of pages in the publication. Information pertaining to the pricing codes can be found in the current issues of the following publications, which are generally available in most libraries: Energy Research Abstracts (ERA); Government Reports Announcements and Index (GRA and I); Scientific and Technical Abstract Reports (STAR); and publication NTIS-PR-360 available from NTIS at the above address. 
P. M. Mathias* and F. P. Stein ${ }^{\star *}$

INTERNATIONAL COAL REFINING COMPANY P.0. Box 2752

Allentown, Pennsylvania 18001

$$
\text { for the }
$$

UNITED STATES DEPARTMENT OF ENERGY

Office of Solvent-Refined Coal Products under Contract DE-AC05-78-0R-03054

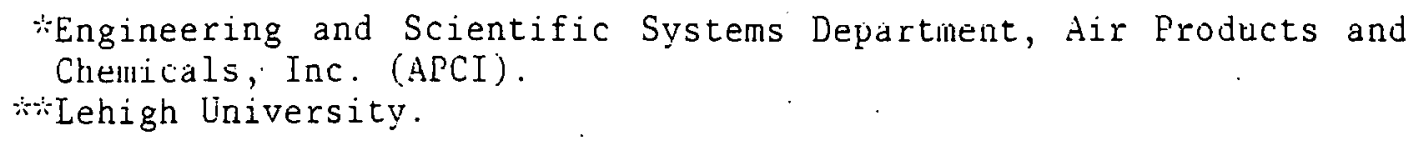
Chemicals, Inc. (APCI). *i:Lehigh University. 
EXECUTIVE SUMMARY

1. INTRODUCTION

2. ENTHALPY OF $t$-DECALIN

3. ENTHALPY OF TERNARY AND QUATERNARY MIXTURES

OF COAL-FLUID MODEL COMPOUNDS

4. DIFFERENTIAL SCANNING CALORIMETRY DATA

5. CONCLUSIONS

LITERATURE CITED - 29

APPENDICES

I. DEFINITION OF COAL-FLUID PSEUDOCOMPONENTS

II. DEFINITION OF LOCAL-COMPOSITION PENG-ROBINSON EQUATION OF STATE - 35 FIGURES - 


\section{ABSTRACT}

The previously developed coal-fluid enthalpy model has been evaluated and enhanced using data on SRC-I fluids and model-compound mixtures measured by researchers at the Colorado School of Mines. In general, good agreement has been obtained with data for SRC-I coal fluids.

Surprisingly, the description of the enthalpy of model-compound mixtures is not as good, indicating that the inevitable lumping of the components in coal-fluid mixtures is advantageous.

The model developed herein will provide the capability for improved designs of several key heat exchangers in the SRC-I process. Further, this work has identified deficiencies in existing models, which suggest . the focus of future research. 


\section{EXECUTIVE SUMMARY}

This report describes the evaluation and enhancement of the enthalpy model developed for the SRC-I process (as well as the other coal-liquefaction processes). Both the initial development and the present analysis have been done by the-Engineering and Scientific Systems Department of Air Products and Chemicals, Inc. (APCI) under subcontract to the International Coal Refining Company (ICRC). A preliminary version of the model was used in the Post-Baseline review of the SRC-I process design (Duffy et al., 1983), and the final version will be employed by APCI in the "ASPEN PLUS Modeling of the SRC-I Demonstration Plant" (APCI, 1984).

ICRC, recognizing the need for thermophysical data on coal liquids and coal-fluid model compounds, embarked upon a 2-year experimental program. Specifically, the overall program objectives were to obtain vapor/liquid equilibrium (VLE) and enthalpy data to develop correlations and verify the designs of several important pieces of process equipment in the SRC-I demonstration plant. The experimental program has been described in detail by Mehta and Chu (1984). The enthalpy portion of the . overall program was subcontracted to the Colorado School of Mines; the data are presented in Vol. 3 of the report by Mehta and Chu (1984) and the final report from the Colorado School of Mines (Mehta, Kidnay and Yesavage, 1984).

The Engineering and Scientific Systems Department of APCI has had a subcontract from ICRC to develop thermophysical property correlations (in particular, phase equilibrium and enthalpy) for use in the design of 
the SRC-I and other coal-1iquefaction processes. Past development work has been described in several publications (Enthalpy: Mathias and Monks, 1982, Mathias and Stein, 1983a; and Mathias and Miller, 1983. Phase equilibrium: Mathias and Stein, 1983b \& c).

The enthalpy model uses a modification of the Peng-Robinson (1976) equation of state proposed by Mathias and Copeman (1983). It was developed mainly from publicly available data on coal fluids and related model compounds (Mathias and Monks, 1982). Analysis of a portion of the data from the ICRC program (Mehta and Chu, 1984) has been presented by Mathias and Stein (1983a). This report presents an analysis of the remaining data from the Colorado School of Mines and the conclusions of the coal-fluid enthalpy model development effort. i

The generalized (predictive) model has provided good agreement with experimental data on coal fluids. Surprisingly, the agreement with the data on model-compound mixtures is not as good. The practical conclusion is that, within the framework of the present model, it is better to lump various types of components within the same pseudocomponent.

The enthalpy model has achieved the main objective of an improved model for the design of several key heat exchangers in the SRC-I process. Further, the work has identified deficiencies in existing models, which suggest the focus of future research. 


\section{INTRODUCTION}

The Engineering and Scientific Systems Department of Air Products and Chemicals, Inc. (APCI) has completed a project to develop a model to predict the enthalpies of coal-fiuid mixtures, in particular the enthalpies of mixtures present in the coal liquefaction section of the SRC-I process. A preliminary version of the model was used in the Post-Baseline review of the SRC-I process design (Duffy et al., 1983), and the final version will be employed by APCI in the "ASPEN PLUS Modeling of the SRC-I Demonstration Plant" (APCI, 1984).

The enthalpy model has been described in previous reports (Mathias and Monks, 1982, Mathias and Stein, 1983a); only details relevant to the present analysis are repeated here. A key feature of the model is the proposed "extended corresponding-states framework." The most successful petroleum models (e.g., Kesler and Lee, 1976) have been based on the three-parameter corresponding-states framework (Pitzer, 1955). Pitzer's theory postulates that the compressibility factor (and thus other derived thermodynamic functions) can be represented at constant temperature and pressure by a linear function of the acentric factor, w. However, the Pitzer framework is inadequate to describe the polar and associative behavior of coal fluids. Thus Mathias and Monks proposed an extended theory by allowing the acentric factor to vary linearly with reduced temperature; the temperature derivative is determined by a new parameter, termed the polar parameter $n$. It should be noted that the "polar parameter" is an empirical, lumped quantity; it is a polar parameter since its value is zero for nonpolar substances. 
The extended corresponding-states framework has been implemented using the "local-composition" Peng-Robinson equation of state (Peng and Robinson, 1976; Mathias and Copeman, 1983). This equation of state is defined in Appendix II. We have already shown that this approach provides a good description of the enthalpy of pure components, even those which are polar (e.g., m-cresol). The description of mixtures is considerably more complex since the binary interaction parameters (see Equations II-3, $4,5)$ must be determined; this issue is addressed in Chapter 3.

It is current practice to treat the fraction of the coal-fluid stream that boils above $n$-pentane $\left(T_{b}>100^{\circ} \mathrm{F}\right)$ as a set of pseudo components, each defined by a range in normal boiling temperature. Thus, the model parameters for each pseudocomponent must be predicted in terms of its measurable properties, termed characterization variables. Correlations for all the model parameters have been developed in terms of the usual characterization variables, normal boiling point and specific gravity (Mathias and Monks, 1982; Mathias and Stein, 1983a \& b). It should be noted that the "correlation" for the polar parameter is only in terms of the boiling point and based on few data for SRC-I fluids (Mathias and Stein; 1983a); its applicability is thus limited to SRC-I fluids - and perhaps to the coal type (Illinois \#6 from the Colonial Mine; see Mehta and Chu, 1984). The components employed in the simulation of the SRC-I are presented in Appendix I.

ICRC has conducted a program to obtain measurements of thermophysical properties in order to provide verification of the current design conditions for the SRC-I demonstration plant and data for developing reliable correlations (Mehta and Chu, 1984). Task 3 of the 
overall program concerns enthalpy measurements and was placed with

Professors Kidnay and Yesavage of the Colorado School of Mines. A portion of this enthalpy data has already been used to evaluate and enhance the enthalpy model (Mathias and Stein, 1983a). The analysis of the remaining data is reported here. Table 1.1 presents a summary of the enthalpy data program; the '.' marks indicate data sets that are analyzed in this report.

Chapter 2 evaluates the model with respect to the enthalpy of t-decalin. Chapter 3 analyses the capability of the model for mixtures containing different types (acid/base/aromatic/saturate, ABAS) of coal-fluid model compounds. Chapter 4 compares the predictions of the model to the heat capacity data on the heavy coal fluids obtained by the differential scanning calorimetry (DSC) method. Finally, Chapter 5 provides an overall assessment of the model and suggests areas for future research. 
Table 1.1

Summary of Task 3: Enthalpy Program

Task 3.1: Process Check Points

- 3.1.1 Bottoms from HP Flash Drum

3.1.2. Overhead from HP Flash Drum

3.1.3' Second Stage MP Flash Drum Overhead - Liquid 1.3H

3.1.4 Wilsonville Process Solvent

Task 3.2: Correlation Check Points

Measurements on four $50^{\circ} \mathrm{F}$ boiling range cuts:

- $700-750^{\circ} \mathrm{F}$

$600-650^{\circ} \mathrm{F}$

$500-550^{\circ} \mathrm{F}$

$400-450^{\circ} \mathrm{F}$

Task 3.3: Mixtures of Heteroatom Compounds

Quinoline

- Decalin

m-Cresol/Quinoline

- m-Cresol/1-Methylnaphthalene/Decalin

- Quinoline/1-Methylnaphthalene/Decal in

- m-Cresol/Quinoline/1-Methylnaphthalene/Decal in

$-7-$ 


\section{ENTHALPY OF $t$-DECALIN}

$t$-Decalin is representative of the saturated naphthenes found in coal fluids. The enthalpy measurements were made in the reference fluid boil-off flow calorimeter (for details see Mehta and Chu, 1984, Vol. 3) at the isobars $20,50,100,150,200,250,456$, and 1500 psia and temperatures up to about $720^{\circ} \mathrm{F}$.

The model compound was first treated as a pseudocomponent described only by its normal boiling point and specific gravity $\left(369.1^{\circ} \mathrm{F}\right.$ and 0.870 , respectively). The results are presented in Figure 2.1. The calculated enthalpies are in reasonably good agreement with the data, but the saturation temperatures calculated by the model are clearly too low. This is mainly due to inaccurate prediction of the critical temperature and pressure; the model predicts values of $739.7^{\circ} \mathrm{F}$ and 431.1 psia, whereas the values reported by Reid et al. (1977) are $782.3^{\circ} \mathrm{F}$ and 455.6 psia, respectively. In particular, the predicted critical temperature is too low.

Figure 2.2 compares the vapor pressures of $t$-decal in from several sources. The dashed line is the model prediction using only the boiling point and specific gravity as input; the open circles are the values estimated from the enthalpy data; the solid circles are the smoothed data recommended by the Coal Conversion Systems Technical Data Book (1979); and finally, the full line is the model prediction if the critical constants from Reid et al. (1977) are used. It is evident that (1) the enthalpy data provides good estimates of the vapor pressure, (2) the characterization correlations for the critical constants are seriously in 
error for this model compound, and (3) the model provides a good description of the vapor pressure of t-decalin if accurate values of the critical constants are used.

It is thus of interest to compare the model calculations with the experimental data if better estimates of the parameters are used. Figure 2.3 presents this comparison; the critical constants and ideal gas heat capacity of $t$-decalin were obtained from the listing in Reid et al. (1977). As expected, a good fit of both the enthalpy and the vapor pressure is obtained.

Close examination of Figures 2.1 and 2.3 indicates that the calculated vapor heat capacities are low at temperatures above about $500^{\circ} \mathrm{F}$. Now, at these conditions the vapor heat capacity is essentially equal to the ideal gas term. (Our calculations indicate that the nonideality contribution to the vapor heat capacity at $500^{\circ} \mathrm{F}$ and 30 psia is approximately $0.01 \mathrm{Btu} / 1 \mathrm{~b}^{\circ} \mathrm{F}$, which is relatively small.) Thus there is a significant difference between calculated and experimental ideal heat capacities.

Table 2.1 presents the ideal gas heat capacity of t-decalin from several sources. The predictions of the pseudocomponent correlation are in reasonably good agreement with those of the correlation in Reid et al. (1977). Further, the values from Reid et al. (1977) agree almost exactly with those reported by Stull et al. (1969), which is a very reliable compilation. Therefore there is significant disagreement between previously accepted values and the present data for the ideal gas heat capacity of $t$-decalin. 
The researchers at the Colorado School of Mines have recognized this problem. After completion of their DOE Contract, the enthalpy data were further screened and additional data were measured. The updated data, which have been presented by Robinson (1984), inclüde a new isobar ( 30 psia) and an extended temperature range (up to $787^{\circ} \mathrm{F}$ ). Figure 2.4 presents a comparison between the enthalpy model and the updated data: There is still a significant discrepancy between experimental and calculated ideal gas heat capacities.

It is not clear whether the accepted values or the experimental data are incorrect. The values reported in Stull (1969) are based on estimation techniques, whereas the experimental values have been produced from a reliable apparatus. Thus, we expect that the experimental data are correct. It should aiso be noted that the impact of these differences upon the process design is very small.

Figure 2.4 also shows that the Peng-Robinson equation predicts inaccurate enthalpies in the critical region. This aspect is beyond the capabilities of a simple model like Peng-Robinson. However, this deficiency will not have any impact upon the process design.

The analysis presented in this chapter leads to the following important conclusions:

1. The vapor pressures derived from the enthalpy data are good. This is evidence of the reliability of the experimental data. 
2. The characteristic correlations are inaccurate in predicting the critical properties of the saturated naphthene t-decalin. However, past experience indicates that the results for full range coal liquids are in good agreement with experimental data.

3. If accurate values of the parameters are employed, the enthalpy model produces good agreement with the data.

4. There is disagreement between previously accepted values and the experimental data for the ideal gas heat capacity of t-decalin. Our feeling is that the experimental data are correct. 
Table 2.1

Ideal Gas Heat Capacity of t-Decalin

\begin{tabular}{lcccc}
\hline & & & Ideal Gas Heat Capacity $\left(B t u / 1 b^{\circ} \mathrm{F}\right)$ \\
\cline { 3 - 5 }$T(\mathrm{~K})$ & $T\left({ }^{\circ} \mathrm{F}\right)$ & Correlation & Reid $(1977)$ & Stul] (1969) \\
\hline 300 & 80.3 & 0.311 & 0.292 & 0.292 \\
400 & 260.3 & 0.411 & 0.412 & 0.411 \\
500 & 440.3 & 0.500 & 0.516 & 0.515 \\
600 & 620.3 & 0.577 & 0.607 & 0.609 \\
700 & 800.3 & 0.641 & 0.684 & 0.685 \\
800 & 980.3 & 0.694 & 0.750 & 0.748 \\
\hline
\end{tabular}




\section{ENTHALPY OF TERNARY AND QUATERNARY MIXTURES}

Experimental data on mixtures of model compounds are very important since specific interactions can be studied. This is especially important in the present case since the interactions between the various pairs of components present in coal fluids can be quite different. There are no known measurements on mixtures of model compounds representing coal fluids: Task 3.3 of the ICRC data program (see Table 1.1) has been designed to provide this important information.

It is convenient to divide coal-fluid components into groups according to their functional groups. The important functional groups include: acids, bases, aromatics, and saturates (ABAS). The mixtures of Task 3.3 have been chosen to provide information on the interactions between components representative of each of these four functional groups:

$$
\begin{aligned}
& \text { acid } \quad \text { - m-cresol } \\
& \text { base } \quad \text { quinoline } \\
& \text { aromatic - } 1 \text {-methylnaphthalene } \\
& \text { saturate - t-decalin }
\end{aligned}
$$

The present correlation treats the coal-fluid mixture as a single distribution of components. In effect, several t:pes (functional groups) of components are lumped into each pseudocomponent. The mixture data provide an opportunity to evaluate the inaccuracies of such an as sumption. 
Future correlation approaches will probably treat the coal-fluid slate as a mixture of several sub-mixtures, each containing a continuous distribution (either boiling-point or molecular-weight) of a particular type of component (e.g., ABAS). For example, Cotterman, Dimitretis and Prausnitz. (1984) report success in treating a petroleum fluid as composed of two sub-mixtures: paraffin and aromatic. Use of this approach with petroleum fluids is relatively simple since the interaction between the paraffin and aromatic types can be assumed to be "ideal." However, a realistic description of coal fluids must also employ acid and base types - with the concomitant nonideal interaction between the sub-mixtures. The analysis of this chapter should provide results useful for such future efforts.

Table 3.1 defines the six ternary and four quaternary mixtures whose. enthalpies were determined by the Colorado School of Mines researchers. The results, again measured in the reference fluid boil-off flow calorimeter, have been presented in the final report by Mehta, Kidnay and - Yesavage (1984). In general, two isobars (30 and 1500 psia) have been reported for each mixture.

The pure-component parameters used for the four model compounds are presented in Table 3.2. m-Cresol, quinoline and 1'methylnaphthalene have been treated as pseudocomponents since previous work (Mathias and Stein, 1983a) has indicated that this produces good results. For t-decalin, the parameters from Reid et ai. (1977) have been used, as described in the previous chapter. 
Model calculations were first made with all the binary interaction parameters (see equations. II-3, 4, and 5) set equal to zero. This may be considered as prediction of the experimental data. The comparisons are presented in Figures 3.1 through 3.9. Examination of these nine figures reveals the following features:

1. The predicted values of the vaporization temperature at a pressure of 30 psia are always high.

2. The predicted enthalpies of vaporization are always low.

3. The predicted liquid heat capacities are slightiy low.

4. The differences between predicted and experimental results increase as the concentration of $\mathrm{m}$-cresol and quinoline increases, although $\mathrm{m}$-cresol tends to produce greater "nonideality."

The local-composition Peng-Robinson equation of state defined' in Appendix II contains 4 interaction parameters for each pair of components. Therefore it is likely that an optimum set of values for the 24 binary parameters can be found which will simultaneously produce a good fit for all nine mixtures of this quaternary system. However that would defeat the purpose of this analysis, which is to study the nature of the interaction between the functional groups. Therefore we decided to employ only the standard Peng-Robinson binary parameter $\left(k_{a}\right.$ in Equation II-3). A further advantage of using only one binary parameter is that generalization to the case of undefined mixtures is less difficult. 
Attempts to find optimum values of the six $k_{a}$ binary parameters were made. We quickly discovered that an improvement in the enthalpy fit resulted in a deterioration of the vapor/liquid equilibrium (VLE) fit, and vice versa. Thus use of only this parameter cannot produce a simultaneous fit of both properties.

Table 3.3 presents the optimum set of parameters that produce a "best" fit of the enthalpy data. It should be noted that a rigorous optimization was not done and, therefore, better results may be obta: ned by fine-tuning the parameters. The m-cresol/quinoline parameter has been set at -0.20 , as determined previously for the binary mixture (Mathias and Stein, 1983a). Interactions between 1-methylnaphthalene and $t$-decalin have been set to the default value (0.0) since a specific interaction between these functional groups is not expected to occur. The data indicate that the interactions of the nonpolar components with m-Cresol are slightly.stronger than those with quinoline. For the sake of brevity, only the results for Ternary 1 (high m-cresol concentration), lernary 2 (high quinoline concentration), and Quaternary 3 (high concentration of $\mathrm{m}$-cresol and quinoline) are presented in Figures $3.10,3.11$ and 3.12 , respectively. These figures indicate that a significantly improved fit of the enthalpy has been obtained, but at the expense of a serious deterioration of the description of phase equilibrium.

Table 3.3 also presents the optimum set of parameters in order to produce a good fit of the VLE. The results for Ternary 1, Ternary 2 and Quaternary 3 are presented in Figures $3.13,3.14$ and 3.15 , respectively. In this case, VLE is much improved, but the enthalpy predictions are poor. 
As mentioned above, use of additional parameters may produce a good description of both VLE and enthalpy with the same set of parameters, but generalization to the case of undefined mixtures will become very difficult. Thus, it appears that the approach of treating the coal-fluid as composed of several sub-mixtures, each containing a single type of component, may be undermined by the necessity of complicated interaction parameters between the sub-mixtures.

On the other hand, the relatively simple approach used currently lumps many types of components into the same pseudocomponent. However, good results were obtained for both the enthalpy and VLE of three full range coal liquids (Mathias and Stein, 1983a) with the assumption that all binary interaction parameters between all pairs of pseudocomponents are equal to the default value of 0.0 . Further, Mathias and Stein also found that an equimolar mixture of m-cresol and quinoline is reasonably well described as a single pseudocomponent. Thus, experimental evidence indicates that the simple approach is effective in practice.

It is not clear why the simple approach produces good results. A reasonable explanation is that each pseudocomponent is a mixture of the four important functional groups (ABAS). Therefore, the nonideal interactions have essentially been accounted for by the polar parameter for each pseudocomponent (Table 4-1). That is, the mixture of pseudocomponents is relatively ideal. 
While the sophisticated approach will probably be superior in the l long run, these problems will have to be overcome first. Additional analysis of the valuable data on this quaternary system may provide the clues to an effective solution. 
Table 3.1

Mixture Identification

Ternary 1: $\quad m$-Cresol/1-Methylnaphthalene/t-Decal in $60.33 / 29.33 / 10.34$ (Mole percent)

Ternary 2: Quinoline/1-Methylnaphthalene/t-Decalin $60 / 30 / 10$ (Mole percent)

Ternary 3: $\quad$-Cresol/1-Methylnaphthalene/t-Decalin 20/40/40 (Mole percent)

Ternary 4: $\quad m$-Cresol/1-Methylnaphthalene/t-Decal in 40/10/50 (Mole percent)

Ternary 5: Quinoline/1-Methylnaphthalene/t-Decal in 10/40/40. (Mole percent)

Ternary 6: Quinoline/1-Methylnaphthalene/t-Dećalin 40/10/50 (Mole percent)

Quaternary 1: $\quad m$-Cresol/Quinoline/1-Methylnaphthalene/t-Decal in 30/15/40/15 (Mole percent)

Quaternary 2: $\quad$ m-Cresol/Quinoline/1-Methylnaphthalene/t-Decal in $15 / 30 / 40 / 15 \quad$ (Mole percent)

Quaternary 3: $\quad$-Cresol/Quinoline/1-Methylnaphthalene/t-Decal in 20/20/40/20 (Mole percent) 


\section{Table 3.2}

Pure-Component Parameters of Model Compunds

\begin{tabular}{|c|c|c|c|c|c|c|}
\hline & $T_{b}\left({ }^{\circ} F\right)$ & $S G$ & MW & $\mathrm{T}_{\mathrm{c}}\left({ }^{\mathrm{O}} \mathrm{F}\right)$ & $P_{c}(p s i a)$ & $\begin{array}{l}\text { Polar } \\
\text { Parameter }\end{array}$ \\
\hline m-Cresol & 396.1 & 1.038 & $113.6^{1}$ & $811.7^{1}$ & $653.7^{1}$ & -0.28 \\
\hline $\begin{array}{l}\text { 1-Methylnaph- } \\
\text {-thalene }\end{array}$ & 472.3 & 1.020 & $144.0^{1}$ & $927.0^{1}$ & $528.3^{1}$ & 0.0 \\
\hline Quinoline & 458.8 & 1.094 & $130.7^{1}$ & $962.6^{1}$ & $658.5^{1}$ & 0.08 \\
\hline$t$-Decalin & 369.1 & 0.870 & $138.3^{2}$ & $782.3^{2}$ & $455.6^{2}$ & 0.0 \\
\hline
\end{tabular}

1 Calculated from pseudocomponent correlations

2 From Reid et al. (1977). 
Table 3.3

Interaction Parameters $\left(k_{2}\right)$ for Coal-Fluid Model Compounds

\begin{tabular}{|c|c|c|c|c|c|}
\hline & & & \multicolumn{3}{|c|}{ Interaction Parameter Set } \\
\hline \multicolumn{3}{|c|}{ Pair } & Default & Enthalpy & VLE \\
\hline m-Cresol & & Quinoline & 0.0 & -0.20 & 0.0 \\
\hline m-Cresol & & 1-Methnaph. & $\dot{0} .0$ & -0.12 & 0.08 \\
\hline m-Cresol & & $t$-Decal in & 0.0 & -0.12 & 0.08 \\
\hline Quinoline & & 1-Methnaph. & 0.0 & -0.08 & 0.04 \\
\hline Quinoline & & $t$-Decalin & 0.0 & -0.08 & 0.04 \\
\hline 1-Methnaph. & - & $t$-Decalin & 0.0 & 0.0 & 0.0 \\
\hline
\end{tabular}




\section{DIFFERENTIAL SCANNING CALORIMETRY DATA}

It was necessary to obtain the experimental data on the heavy samples $\left(700-750^{\circ} \mathrm{F}\right.$ fraction and $V-110$ Bottoms, see Table 1.1) using the differential scanning calorimetry (DSC) method. The Colorado School of Mines researchers have stated (Mehta and Chu, 1984, Vol. 3) that the reason is that the samples are solid at room temperature and, therefore, it was not feasible to run them in the flow calorimeter without drastic equipment modifications.

The DSC method is well suited to measuring the heat capacities of solid and liquid samples. However, the apparatus and instrumentation of DSC prohibit scanning at temperatures where vaporization occurs; the samples are encapsulated, but not sealed, at approximately atmospheric pressure. Any significant vaporization loss not orly results in poor heat capacity measurements, but also damages the calorimeter. For these reasons, an upper limit of $512^{\circ} \mathrm{F}$ was set for both samples. The CSM researchers have stated that this upper limit was satisfactory for the V-110 Bot.toms, but apparently not for the $700-750^{\circ} \mathrm{F}$ distillation fraction since a total weight loss of about $10 \%$ occurred during the scanning process.

Only smoothed values of the heat capacity have been presented in the report by CSM. However, we preferred to have the actual measurement. At our request, Professor Kidnay of CSM supplied us with the "raw" data.

DSC measurements were first made on the $600-650^{\circ} \mathrm{F}$ fraction. These data intentionally overlap previous measurements made with the flow 
calorimeter. The reliability of the latter method has been established and thus can be used as a check on the DSC apparatus and procedure. Kidnay and Yesavage (Vol. 3 of Mehta and Chu, 1984) have reported that the DSC data are about 4-7\% greater than the "true" (flow cálorimeter) values for this material: Figure 4.1 presents a comparison between the DSC data and the present enthalpy model. The calculated results with the polar parameter optimized from the flow cell measurements $(\eta=-0.15$, Mathias and Stein, 1983a; al so see Figure A-2) also indicate that the DSC data are high, by about the same amount.

Figure 4.2 presents a comparison between the DSC data and calculated results for the $700-750^{\circ} \mathrm{F}$ distillation cut. The gap in the experimental data between 10 and $142^{\circ} \mathrm{F}$ is due to a phase transition in the coal liquid. The two calculated curves shown are with the predicted value of the polar parameter $(\eta=-0.12$, Figure $A-2)$ and the default value of zero. Both curves generally underpredict the data. However, it should be noted that comparisons with the $600-650^{\circ} \mathrm{F}$ cut indicate that the - DSC measurements are biased high and, therefore, the predictions (full line) may be close to the "true" value. At $300^{\circ} \mathrm{F}$, the predicted value $\left(0.466 \mathrm{Btu} / 1 \mathrm{~b}^{\circ} \mathrm{F}\right)$ is $5 \%$ lower than the measured liquid heat capacity $\left(0.49 \mathrm{Btu} / 1 \mathrm{~b}^{\circ} \mathrm{F}\right)$.

The OSC data indicate that the liquid heat capacity levels off sharply at the higher temperatures $\left(T>400^{\circ} \mathrm{F}\right)$; this is inconsistent both with the predicted behavior and past results from the flow cell. One possible explanation is that the reported $10 \%$ sample loss occurs at about $400^{\circ} \mathrm{F}$. 
Simulated gas chromatographic analyses performed at both APCI and CSM (Vols. 1 and 3 of Mehta and Chu, 1984) indicate that about $35-40 \%$ of the $700-750^{\circ} \mathrm{F}$ fraction boils below $700^{\circ} \mathrm{F}$. Therefore, an additional calculation was made assuming this fraction is a $40 / 60$ (by weight) mixture of two fractions, $650-700^{\circ} \mathrm{F}$ and $700-750^{\circ} \mathrm{F}$. However, this only results in a small increase in the predicted liquid heat capacity. For example, at $300^{\circ} \mathrm{F}$, the value increases from 0.466 to 0.4728 tu $/ 1 b^{\circ} \mathrm{F}$.

It is of interest to compare the present data to the data measured by Gulf on similar SRC-II boiling fractions and also using the DSC procedure (Gray, 1981). The results, presented in Figure 4.3, indicate that the temperature dependence of the heat capacity of SRC-II liquids is markedly higher than that of SRC-I liquids. This is highly unlikely and therefore the differrence must be due to an error in the DSC method, which has an unproven record of reliability. Since the predicted curve, which is based on the flow calorimeter data, shows better agreement with the DSC data from the Colorado School of Mines, it appears that Gulf's data may be in error.

Table 4.1 and Figure 4.4 show the boiling-point distribution of $V-110$ Bottoms in comparison to the three liquids already anaiyzed (Mathias and Stein, 1983a). It is clear that $V-110$ is the heaviest of the four coal liquids. Figure 4.5 presents a comparison between the data and calculated results. As opposed to the comparisons for the $600-650^{\circ} \mathrm{F}$ and $700-750^{\circ} \mathrm{F}$, the predicted results are higher than the DSC data. Again, the data show an unexpected levelling off at the higher temperatures; this time, however, the sample loss during the scanning process was negligible. 
One anomalous point is that the data do not show the expected solid/liquid phase transition.

We are not sure whether the differences are caused by errors on the part of the model or the data. This issue cannot be resolved until the reliability and accuracy of the DSC method are established. In any event, the differences between predicted values and the data are reascnably small (5-15\%) and, therefore, the impact upon the design may be correspondingly smal1. 
Table 4.1

Component Distribution of SRC-I Coal Liquids

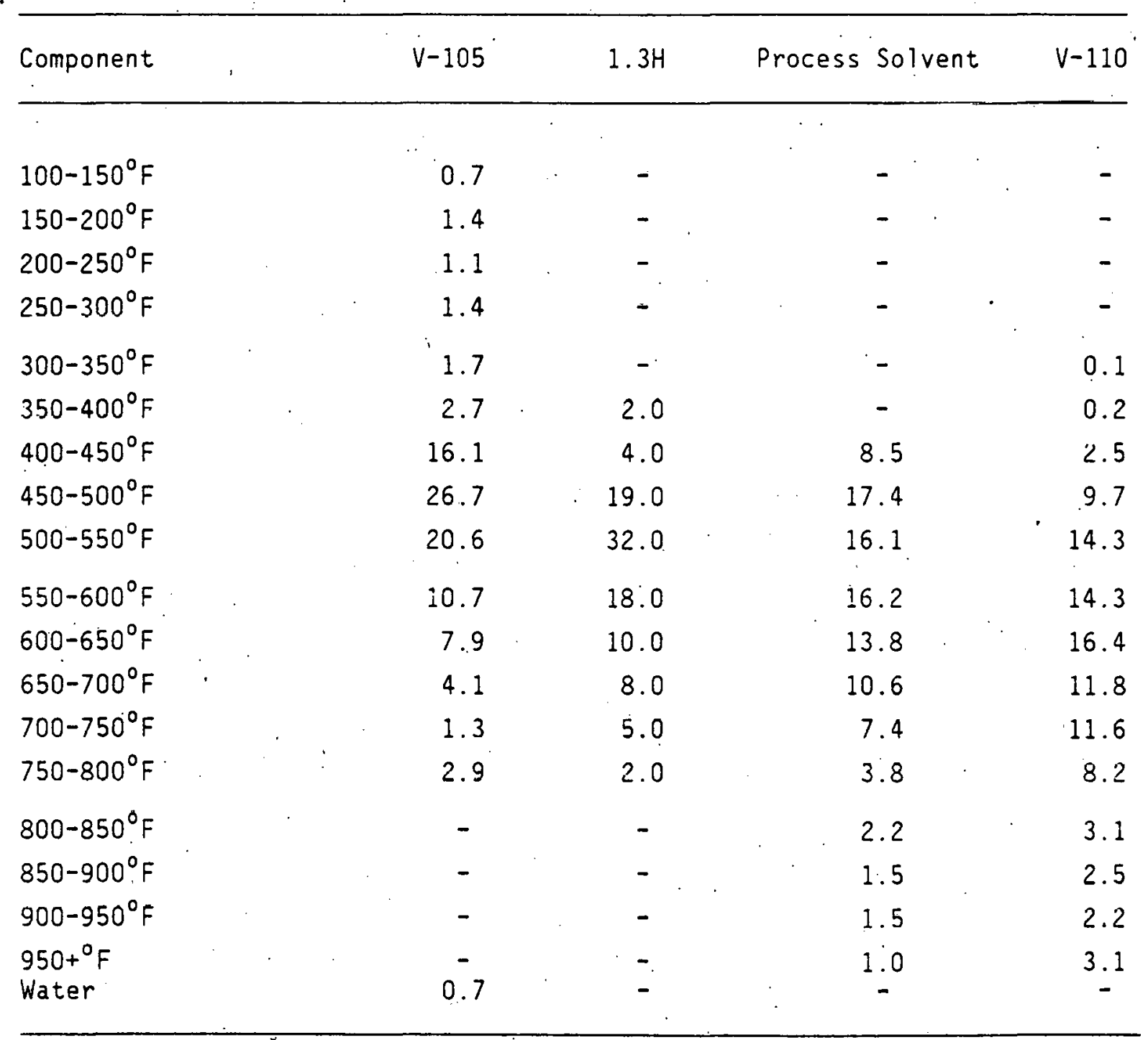




\section{CONCLUSIONS}

The enthalpy model developed in this project has produced good agreement with the data on coal fluids measured by the flow calorimeter. Comparison with the data on three full-range coal liquids $(\mathrm{V}-105,1.3 \mathrm{H}$ Blend and Process Solvent) indicates that the enthalpy as well as the VLE can be adequately described. Thus the model should enable improved designs of several key heat exchangers in the coal liquefaction section of the SRC-I process.

Comparison with the experimental data on the heavier coal liquids for which the DSC method. was used did not lead to any definite conclusions, mainly due to the unproven reliability of the OSC technique. However, the differences between the predicted results and the data are not large.

The present correlation approach divides the coal-fluid mixture into a single distribution - in effect, lumping several types of functional groups into each pseudocomponent. This simple approach appears to have the unexpected advantage that a good description of the properties of full-range coal liquids (i.e., mixtures of pseudocomponents) can be obtained without the complication of non-zero interaction parameters between pseudocomponents in the equation of state.

However, long term development of thermophysical models will surely benefit from the sophisticated approach of assuming that the coal-fluid is made up of several continuous distributions, each containing only a particular type of component. The model-compound mixture data analysed in this work are very important in this regard since they provide an 
indication of the interaction effects between types of components. The analysis presented herein indicates that these interaction effects are significant -- and are not amenable to description by simple means. This is an important problem that requires research attention.

Finally, this work has not addressed the development of models for the heavy $\left(950+^{\circ} \mathrm{F}\right)$ fraction. This is another problem which requires future research. 


\section{LITERATURE CITED}

Air Products and Chemicals, Inc. 1984. ASPEN PLUS Modeling of the SRC-I Demonstration Plant. Task 408.4, International Coal Refining Company, Allentown, PA.

Brule, M. R., R. W. Corbett and S. Watanasini. 1982. Computer-Aided Design of the CSO Process in the SRC-I Demo Plant. Presented at API 47 th Midyear Refining Meeting, New York, May 12.

Coal Conversion Systems Technical Data Book. Prepared for U. S. Department of Energy under contract No. EX-76-C-01-2286. IB.30-5, page 10, May 1979.

Cotterman, R. L. and J. M. Prausnitz. 1984. Flash Calculations for Continuous or Semi-Continuous Mixtures Using an Equation of State. Submitted for publication in Ind. Eng. Chem. Proc. Des. Dev.

Cotterman, R. L., D. Dimitrelis and J. M. Prausnitz. 1984. Supercritical-Fluid Extraction Calculations for High-Boiling Petroleum Fractions using Propane. Application of Continuous Thermodynamics. To be published in Ber. Bunsen. Physik. Chem., 87(9).

Duffy, R. S., T. D. Vakil and G. D. Gimson. 1983. ASPEN Simulation of the SRC Process Area Baseline Design Using Coal Liquid Thermophysical Property Models. DOE/OR/03054-76. International Coal Refining Company, Allentown, PA.

Gonsalves, J. B., P. M. Mathias and F. P. Stein. 1984. Phase Equilibrium Studies - Final Report. DOE/OR/03054-111. International Coal Refining Company, Allentown, PA.

Gray, J. A. 1981. Selected Physical, Chemical and Thermodynamic Properties of Narrow Boiling Range Coal Liquids for the SRC-II Process. Interim report for the period March 1980 to February 1981. DOE/ET/10104-7.

Gray, J. A. and G. D. Holder. 1982. Selected Physical, Chemical, and Thermodynamic Properties of Narrow Boiling Coal Fluids from the SRC-II Process, Supplemental Property Data. DOE/ET/10104-44.

International Coal Refinining Company. 1984. SRC-I Baseline Design Technical Data Book. DOE/OR/03054-23. International Coal Refining Company, Allentown, PA, February.

Kesler, M. G. and B. I. Lee. 1976. Improve Enthalpy of Fractions. Hydrocarbon Processing. March:153-158.

Mathias, P. M. and T.W. Copeman. 1983. Extension of the Peng-Robinson Equation of State to Complex Mixtures: Evaluation of Various Forms of the Local Composition Concept. Fluid Phase Equilibium, 13:91-108. 
Mathias, P. M. and E. J. Miller. 1983. An Enthalpy Model for Coal

Fluids. Presented at the Annual AIChE Meeting, Washington, D.C., 30 October - 4 November.

Mathias, P. M. and K. G. Monks. 1982. Computer Model for Determining the Enthalpy of Coal Fluids. Pages 227-272 in SRC-I Quarterly Technical Report, April-June. DOE/OR/03054-8. International Coal Refining Company, Allentown, PA.

Mathias, P. M. and F. P. Stein. 1983a. Enthalpy Studies. DOE/OR/03054-66. International Coal Refining Company, Allentown, PA.

Mathias, P. M. and F. P. Stein. 1983b. Preliminary Phase Equilibrium Model for the SRC-I Process. Pages 103-147 in SRC-I Quarterly Technical Report, January-March. DOE/OR/03054-17. International Coal Refining Company, Allentown, PA.

Mathias, P. M. and F. P. Stein. 1983C. Phase Equilibrium Studies. DOE/OR/03054-67. International Coal Refining Company, Allentown, PA.

Mehta, D. C. and I. C. Chu. 1984. Subcontracted R\&D Final Report: SRC-I Phase Equilibrium and Enthalpy Data for Coal Liquefaction and Solvent Recovery Areas. DOE/OR/03054-96.

Mehta, D. C., A. J. Kidnay, and V. F. Yesavage. 1984. Subcontracted R\&D Final Report. Enthalpy Data for Coal Liquefaction and Solvent Recovery Areas - Mixtures of Model Compounds. DOE/OR/03054 -105. International Coal Refining Company, Allentown, PA.

Peng, D. Y. and D. B. Robinson. 1976. A New Two-Constant Equation of State. Ind. Eng. Chem. Fundam., 15:59-64.

Pitzer, K. S. 1955. J. Amer. Chem. Soc., 77:3427.

Reid, R. C., J. M. Prausnitz, and T. K. Sherwood. 1977. The Properties of Gases and Liquids, 3rd ed. McGraw-Hill Book Company, New York.

Robinson, D. S. 1984. Enthalpy Measurements on trans-Decalin. M. S. Thesis \#2849, Colorado School of Mines.

Stull, D. R., E. F. Westrum, Jr., and G. C. Sinke. 1969.' The Chemical Thermodynamics of Organic Compounids. John Wiley \& Sons, Inc., New York. 


\section{APPENDIX I}

\section{Definition of SRC-I Components}

The components being used currently in the simulation of the SRC-I process are similar to those previously employed for the SRC-I Baseline Design (International Coal Refining Company, 1984) and the Post-Baseline review of the SRC-I process design (Duffy et al., 1983). These are divided into pure components and pseudocomponents. The pure components are hydrogen, nitrogen, argon, ammonia, hydrogen chloride, carbon monoxide, carbon dioxide, oxygen, hydrogen sulfide, carbonyl sulfide; sulfur dioxide, methane, ethane, propane, n-butane, n-pentane and water. All of these are common components whose properties are well established.

It is current practice to treat the essentially continuous coal-fluid slate as a set of pseudocomponents, each determined by a range in normal boiling temperature. As in the baseline design, the pseudocomponents have been defined to be $50^{\circ} \mathrm{F}$ cuts starting from $100^{\circ} \mathrm{F}$ and up to $950^{\circ} \mathrm{F}$.

All the heavy material $\left(950+{ }^{\circ} \mathrm{F}\right)$ has been lumped into a cut assumed to boil at $1050^{\circ} \mathrm{F}$. The SRC-I pseudocomponents are presented in Table A-1.

The practice of treating the coal-fluid mixture as a set of pseudocomponents is somewhat arbitrary and may also cause excessive computational loads. Recent research (for example, Cotterman and Prausnitz, 1984) suggests that it is advantageous to treat this mixture as a continuous distribution - continuous thermodynamics. Although extremely promising, continuous thermodynamics is not yet ready for industrial application. 
A further problem arises from the assumption that all the heavy material $\left(950+{ }^{\circ} \mathrm{F}\right.$ ) can be lumped into a single pseudocomponent, since a few streams in the SRC-I process contain up to $50 \%$ material boiling above $950^{\circ} \mathrm{F}$. One possible solution is to divide the $1050^{\circ} \mathrm{F}$ cut into several high-boiling components. For example, Brule et al. (1982) have used 14 hypothetical components, with normal boiling points of 975 to $1625^{\circ} \mathrm{F}$ in $50^{\circ} \mathrm{F}$ increments, to describe this portion of the mixture in their simulation of the critical-solvent-deashing (CSD) section of the SRC-I demonstration plant. This assumption could easily be adopted here, but we have no experimental evidence to select a particular set and relative composition of the high-boiling pseudocomponets. Further, all the experimental data analyzed in this report is on $950{ }^{\circ} \mathrm{F}$ material. As has been noted by many investigators, the area of characterization of heavy fractions requires much more experimental and theoretical research.

In addition to the boiling point, other characterizing variables must be specified for each pseudocomponent. The specific gravities shown in Table A-1 are those employed by Gulf for the SRC-II process (Gray and Holder, 1982). Limited comparisons with experimental data (Vol. I of Mehta and Chu, 1984) have indicated that these specific gravities are also appropriate for SRC-I fluids. Most of the pure-component parameters are determined in terms of the normal boiling point and specific gravity by employing correlations presented previously (Mathias and Monks, 1982, and Mathias and Stein, 1983b). The parameters for which correlations are available are the critical temperature, critical pressure, molecular weight, and the constants in the polynomial for the ideal gas heat capacity. We have chosen to override the correlation for the molecular 
weight and instead use the values employed in the SRC-I Baseline Design; the differences introduced are small $(<5 \%)$.

The only required parameter for which a correlation has yet to be developed is the polar parameter. We have chosen the values presented in Table A-1. As noted by Mathias and Stein (1983a), the "polar parameter" lumps all effects not accounted for by the boiling point and specific gravity. It is thus an empirical quantity for which a generalized correlation may not be possible. However, it is reasonable to expect that polarity - and hence heteroatomicity - will strongly affect its value.

The values presented in Table A-1 are only an educated guess which reflects the fact that the heteroatom-containing substances are concentrated in the boiling range, $300-600^{\circ} \mathrm{F}$.

In the event that coal-fluid pseudocomponents are defined differently from those presented in Table $A-1$, Figures $A-1$ and $A-2$ provide a means of estimating the specific gravity and polar parameters, respectively. 
Table A-1.

Characteristic Parameters Assumed for SRC-I Pseudocomponents

\begin{tabular}{|c|c|c|c|c|c|c|}
\hline \multirow{2}{*}{$\begin{array}{c}\text { Boiling Range } \\
{ }^{\circ} \mathrm{F}\end{array}$} & \multicolumn{2}{|c|}{$\begin{array}{l}\text { Normal } \\
\text { Boiling }\end{array}$} & \multirow{2}{*}{$\begin{array}{l}\text { Specific } \\
\text { Gravity }\end{array}$} & & \multirow{2}{*}{$\begin{array}{l}\text { Molecular } \\
\text { Weight }\end{array}$} & \multirow{2}{*}{$\begin{array}{c}\text { Polar } \\
\text { Parameter }\end{array}$} \\
\hline & Point & ${ }^{\circ} \mathrm{F}$ & & . & & \\
\hline $\begin{array}{l}100-150 \\
150-200 \\
200-250 \\
250-300 \\
300-350\end{array}$ & $\begin{array}{l}125 \\
175 \\
225 \\
275 \\
325\end{array}$ & & $\begin{array}{l}0.6800 \\
0.7360 \\
0.7720 \\
0.8142 \\
0.8620\end{array}$ & . & $\begin{array}{r}78.43 \\
88.40 \\
97.58 \\
107.49 \\
118.08\end{array}$ & $\begin{array}{l}0 \\
0 \\
-0.074 \\
-0.145 \\
-0.212\end{array}$ \\
\hline $\begin{array}{l}350-400 \\
400-450 \\
450-500 \\
500-550 \\
550-600\end{array}$ & $\begin{array}{l}375 \\
425 \\
475 \\
525 \\
575\end{array}$ & & $\begin{array}{l}0.9328 \\
0.9680 \\
0.9698 \\
0.9881 \\
1.0122\end{array}$ & . & $\begin{array}{l}130.62 \\
143.29 \\
155.18 \\
170.01 \\
188.02\end{array}$ & $\begin{array}{l}-0.266 \\
-0.310 \\
-0.320 \\
-0.275 \\
-0.200\end{array}$ \\
\hline $\begin{array}{l}600-650 \\
650-700 \\
700-750 \\
750-800 \\
800-850\end{array}$ & $\begin{array}{l}625 \\
675 \\
725 \\
775 \\
825\end{array}$ & & $\begin{array}{l}1.0328 \\
1.0679 \\
1.0966 \\
1.1168 \\
1.1375\end{array}$ & & $\begin{array}{l}201.61 \\
218.29 \\
237.04 \\
256.05 \\
277.98\end{array}$ & $\begin{array}{l}-0.150 \\
-0.132 \\
-0.122 \\
-0.114 \\
-0.105\end{array}$ \\
\hline $\begin{array}{l}850-900 \\
900-950 \\
950+\end{array}$ & $\begin{array}{r}875 \\
925 \\
1050\end{array}$ & & $\begin{array}{l}1.1570 \\
1.1752 \\
1.2177\end{array}$ & $\cdot$ & $\begin{array}{l}297.00 \\
321.50 \\
450.00\end{array}$ & $\begin{array}{l}-0.095 \\
-0.085 \\
-0.056\end{array}$ \\
\hline & & & & & & \\
\hline
\end{tabular}


Definition of the Local-Composition Peng-Robinson Equation of State

According to the modified Peng-Robinson equation proposed for mixtures, the pressure is given as a function': of temperature and molar volume as follows:

$$
P=\frac{R T}{v-b}-\frac{1}{v(v+b)+b(v-b)}\left\{a+\frac{a^{N C}}{2 R T} F_{v}\right\}
$$

The quantity $F_{v}$ has been introduced to simplify the notation

$$
F_{v}=\frac{1}{2 \sqrt{2} b} \ln \left[\frac{v+(1+\sqrt{2}) b}{v+(1-\sqrt{2}) b}\right]
$$

$a, a^{N C}$, and $b$ are mole fraction averaged quantities as defined below:

$$
\begin{aligned}
& a=\sum_{i j} \sum x_{i} x_{j}\left(1-k_{a j i}\right)\left(a_{i} a_{j}\right)^{\frac{1}{2}} \\
& a^{N C}=\sum_{i} x_{i}^{2} a_{c i}{ }^{2} \sum_{j} x_{j} t_{j i} \\
& b=\sum_{i j} x_{i} x_{j}\left(1-k_{b j i}\right)\left(b_{i}+b_{j}\right) / 2
\end{aligned}
$$

The pure component quantities in equations II- 3, II- 4; and II- 5 are. defined in terms of the critical temperature $\left(T_{C}\right)$, the critical pressure $\left(p_{c}\right)$, and parameters $\left(c_{1} ; c_{2}\right.$, and $c_{3}$ ) designed to describe the vapor pressure: 


$$
\begin{gathered}
a_{i}=a_{c i} \alpha_{i} \\
a_{c i}=0.45724 R^{2} T_{c i}{ }^{2 / P_{c i}} \\
\alpha_{i}=\left[1+c_{1 i}\left(I-V T_{r i}\right)+c_{2 i}\left(I-V T_{r i}\right)^{2}+c_{3 i}\left(I-V T_{r i}\right)^{3}\right] 2(I I-6) \\
b_{i}=0.07780 R T_{c i} / P(I-8)
\end{gathered}
$$

All configurational properties can be derived from the equation of state defined above using standard thermodynamic relationships. The Helmholtz energy of a mixture is given by

$$
\bar{A}=-R T \ln (v-b)-a F_{v}-\frac{a^{N C}}{2 R T} F_{v}{ }^{2}
$$

The fugacity coefficient of component $i$ in an n-component mixture is given by

$$
\begin{aligned}
& \ln \left(\phi_{i}\right)=\ln \left[\frac{R T}{P(v-b)}\right]+(I-z)-\left\{a+a^{N C} \frac{F_{v}}{R T}\right\} \frac{F_{v}}{R T} \\
& +2 \sum_{j} x_{j} b_{j i} / b\left[z-1+\left\{a+a^{N C} \frac{F_{v}}{R T}\right\} \frac{F_{v}}{R T}\right]-2 \frac{F_{v}}{R T} \underset{j}{\Sigma} x_{j} a_{j i}
\end{aligned}
$$

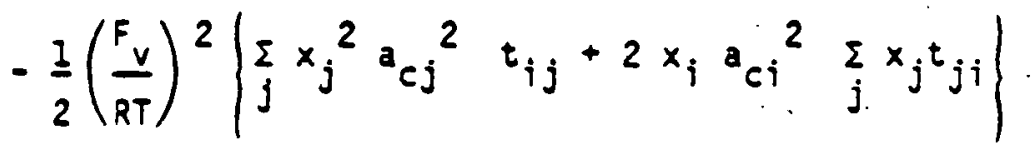


Figure 2.1

Enthalpy of t-Decalin: Peng-Robinson Vs. Experimental Data (Treated as Pseudocomponent, $\mathrm{TB}=369.1^{\mathrm{F}} \mathrm{F} \mathrm{SG}=.870$ )

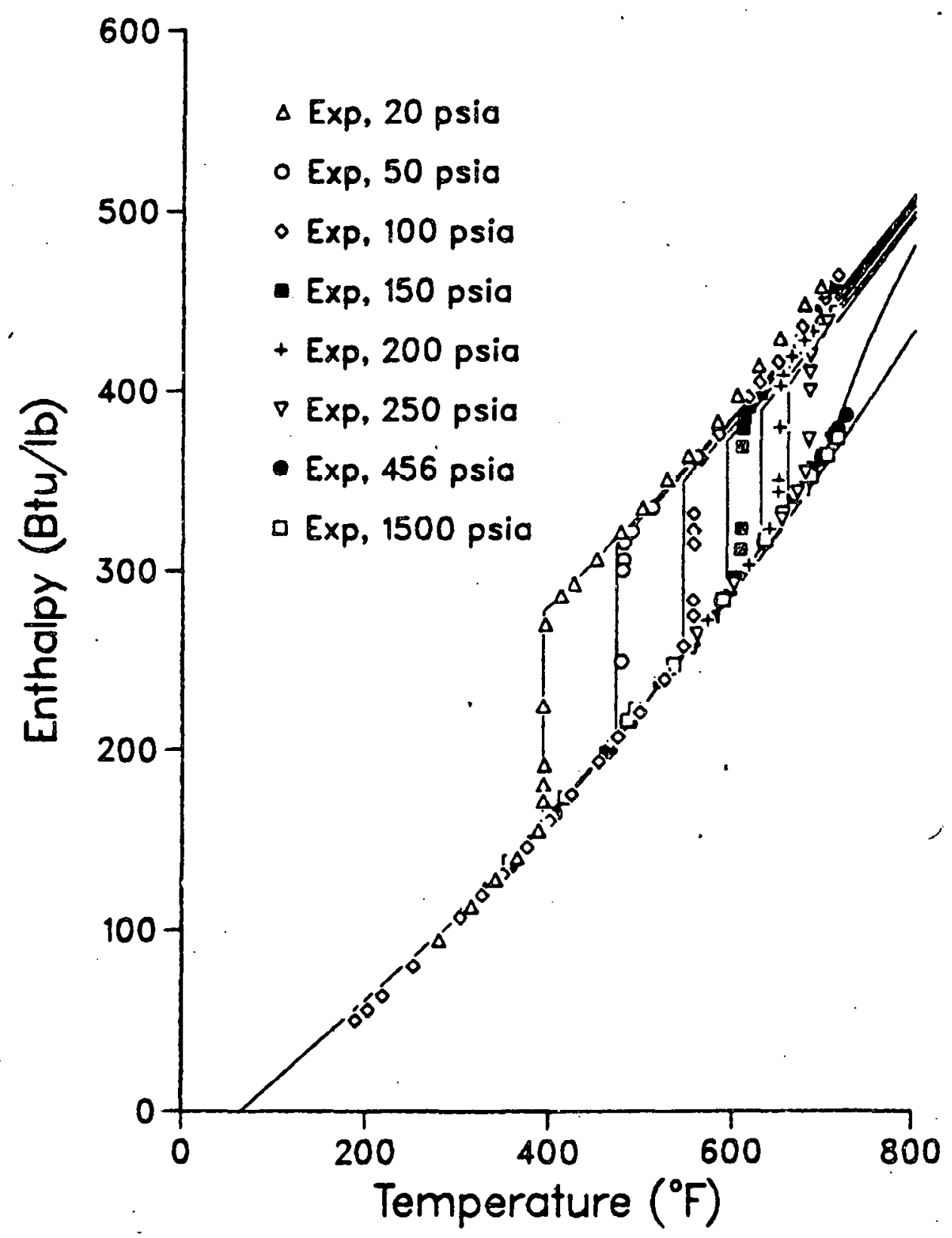




\section{Figure 2.2 \\ Vapor Pressure of $t$-Decalin}

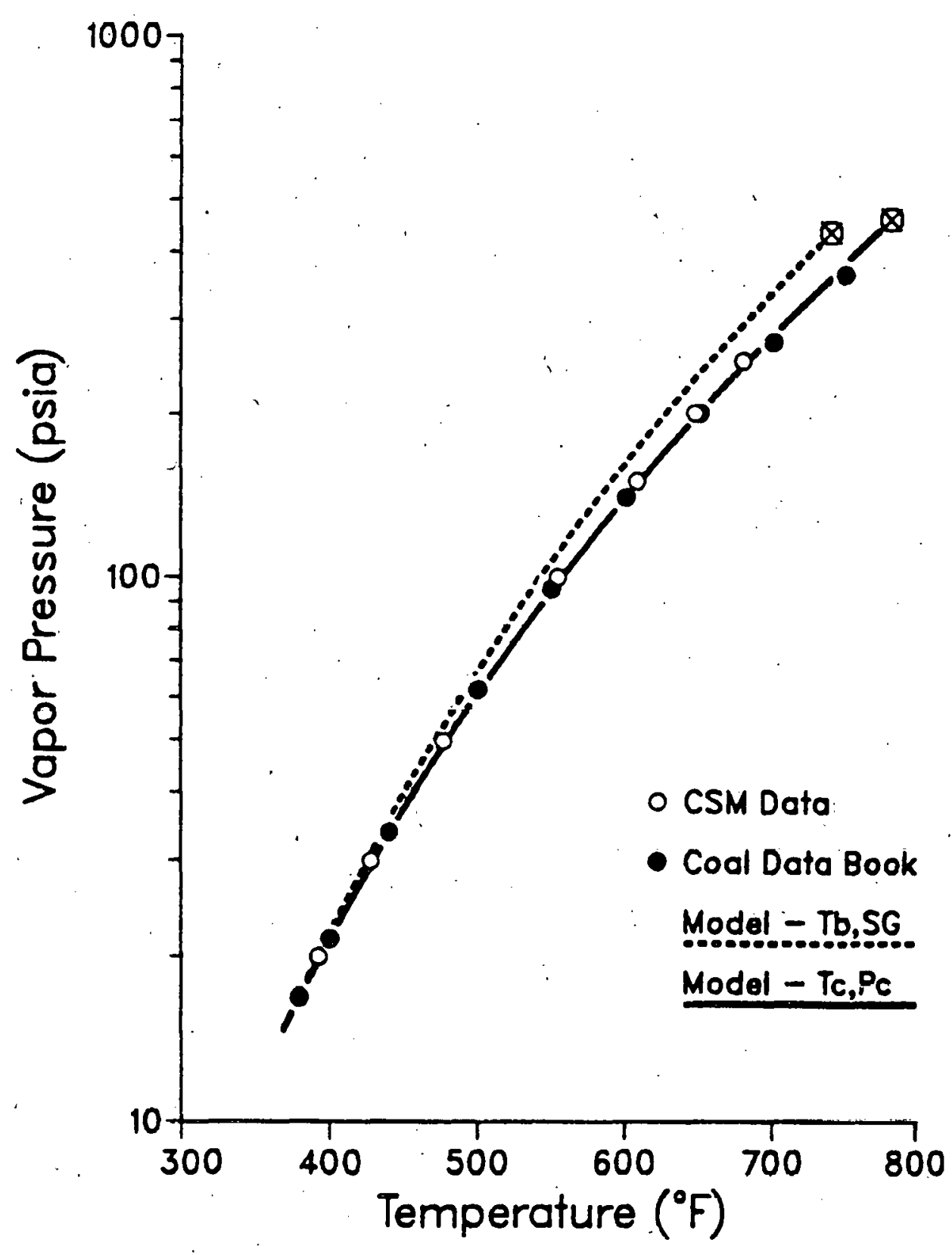


Figure 2.3

Enthalpy of t-Decalin: Peng-Robinson Vs. Experimental Data (Decalin properties from Reid et al., 1977)

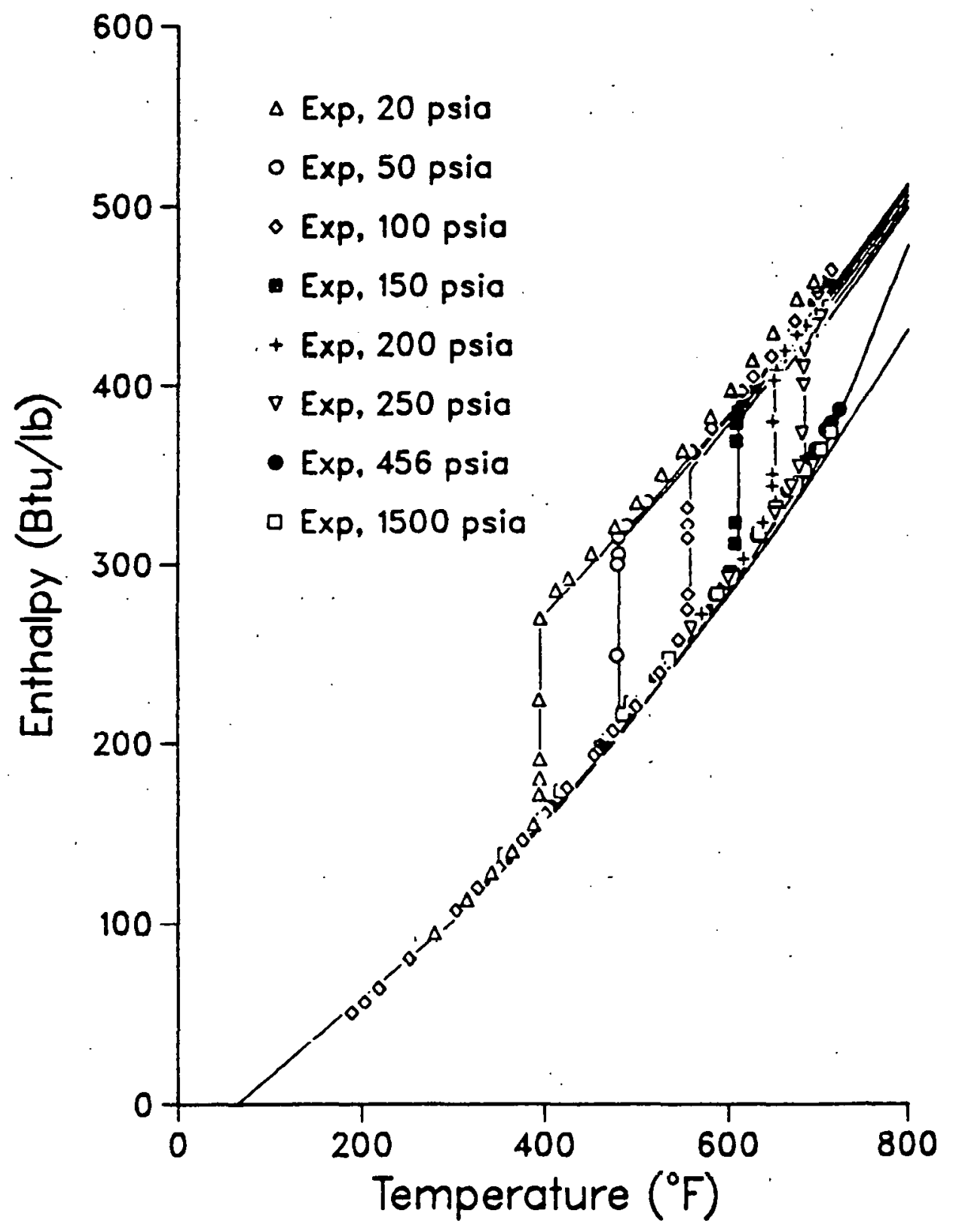


Figure 2.4

Enthalpy †-Decalin: Peng-Robinson Vs. Data of Robinson (1984) (Decalin properties from Reid et al., 1977)

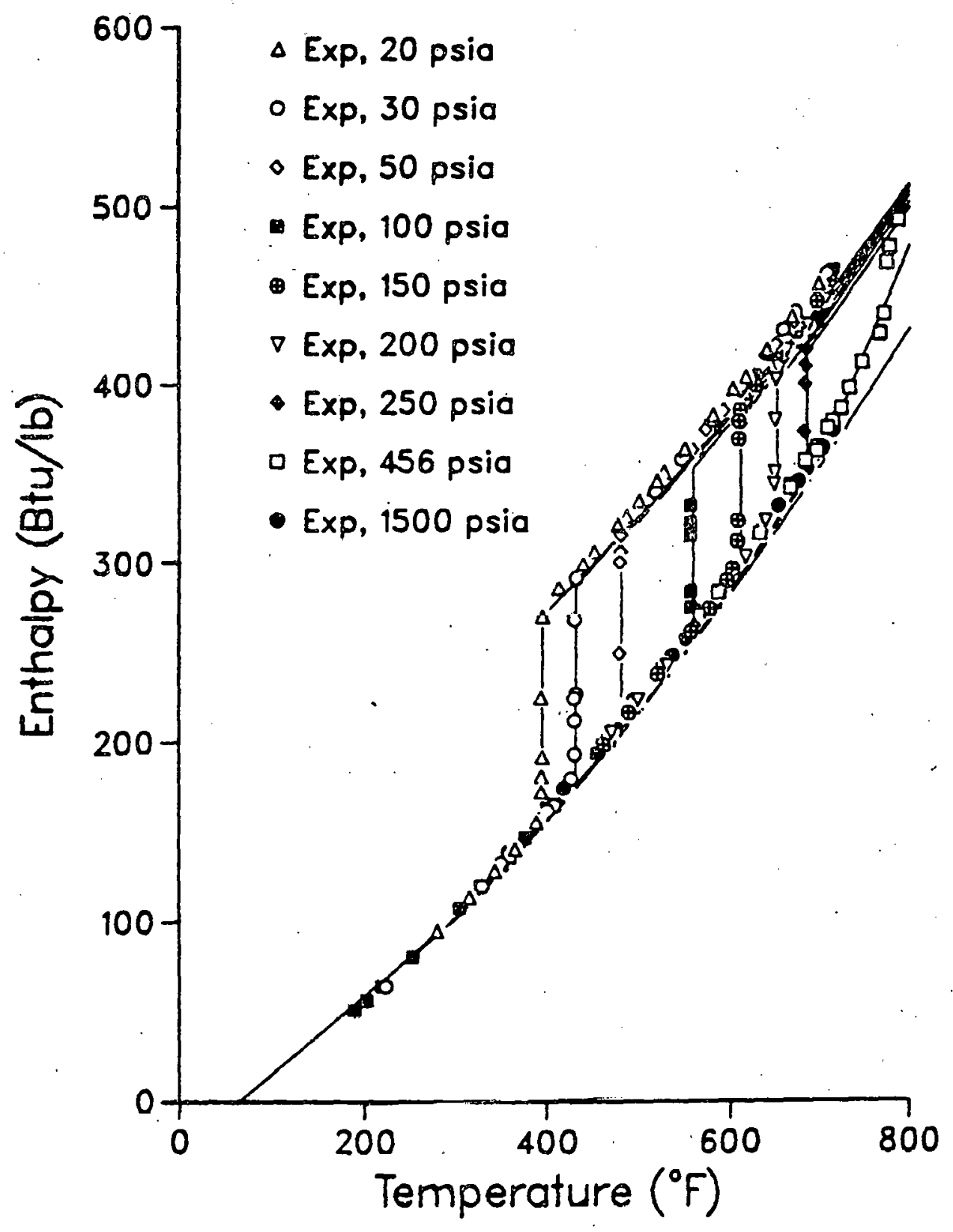


Figure 3.1

Enthalpy of $m$-Cresol/1-Methylnaphthalene/t-Decalin Composition: 60.33/29.33/10.34 Interaction Parameters: Default (Table 3.3)

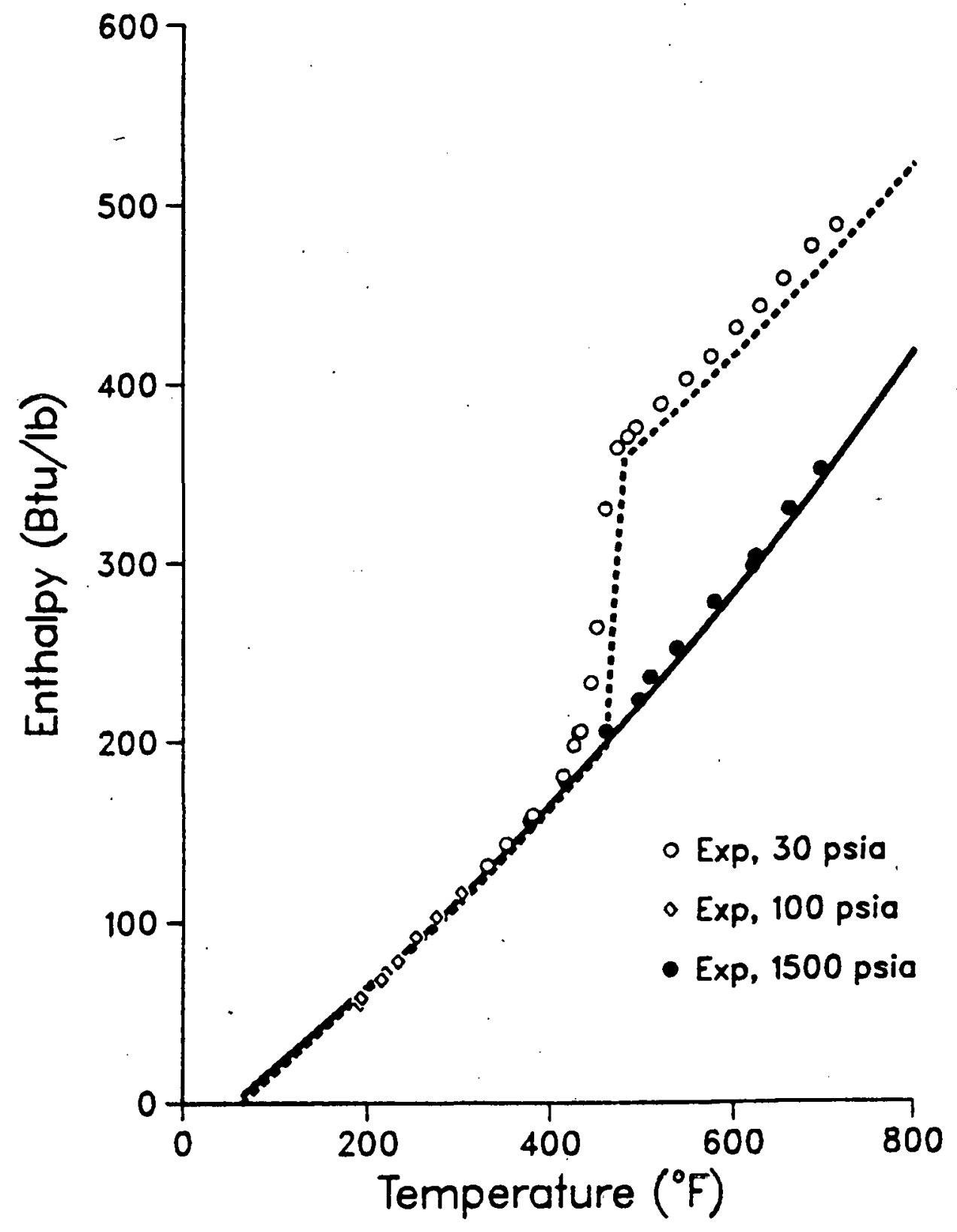


Figure 3.2

Enthalpy of Quinoline/1-Methylnaphthalene/t-Decalin Composition: 60/30/10 Interaction Parameters: Default (Table 3.3)

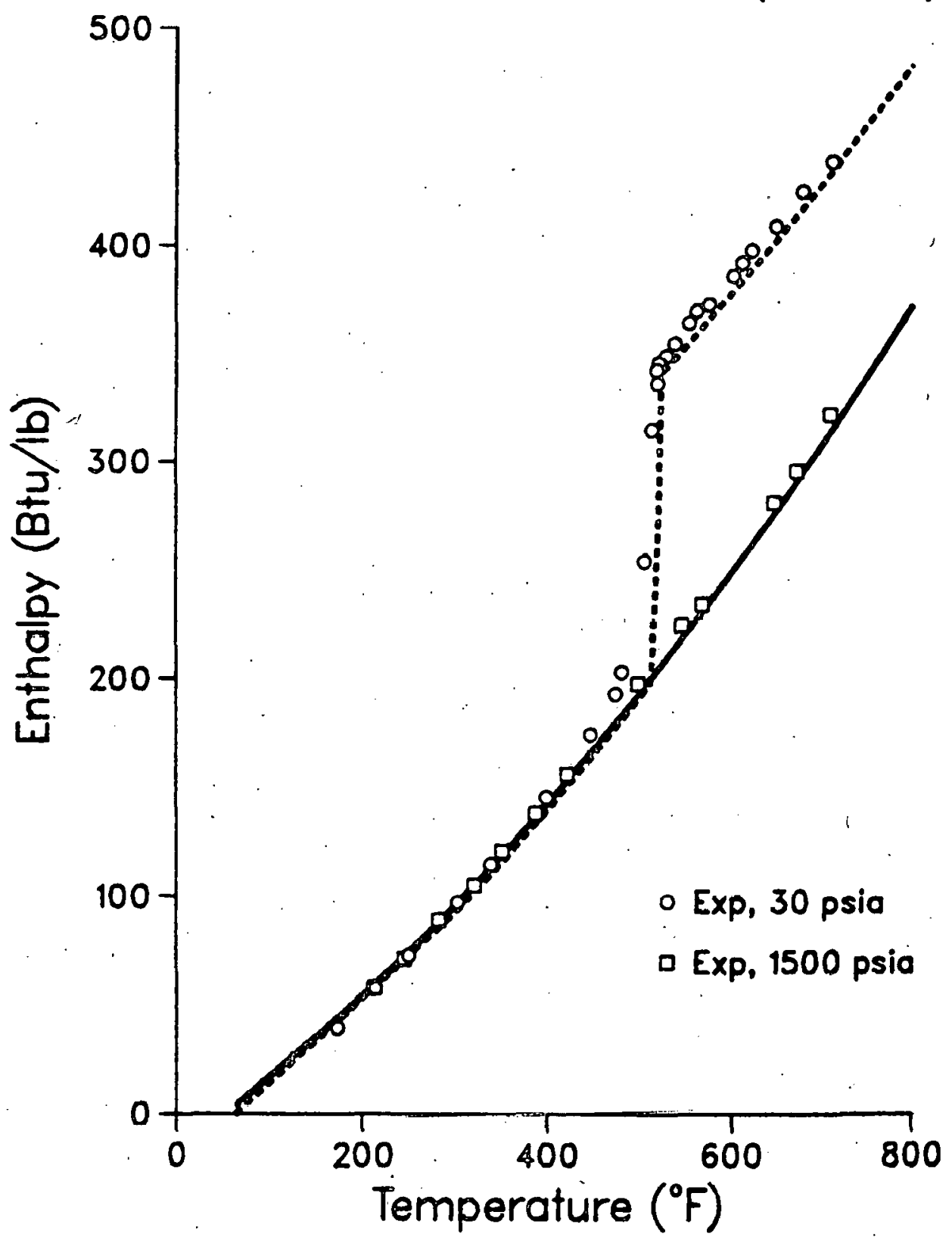


Figure 3.3

Enthalpy of $m$-Cresol/1-Methylnaphthalene/ $t$-Decalin Composition: 20/40/40 Interaction Parameters: Default (Table 3.3)

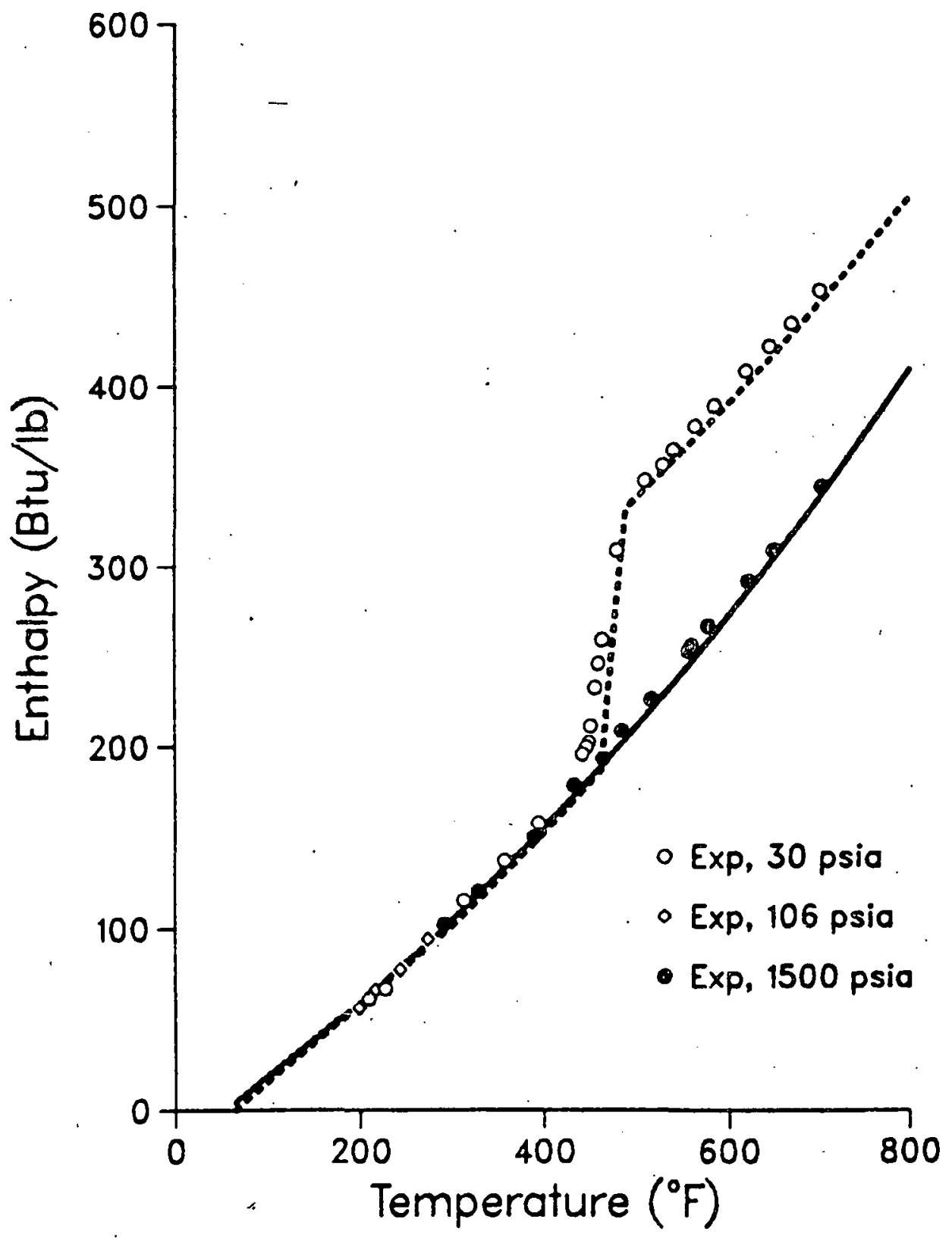


Figure 3.4

Enthalpy of $m$-Cresol/1-Methylnaphthalene/t-Decalin Composition: 40/10/50

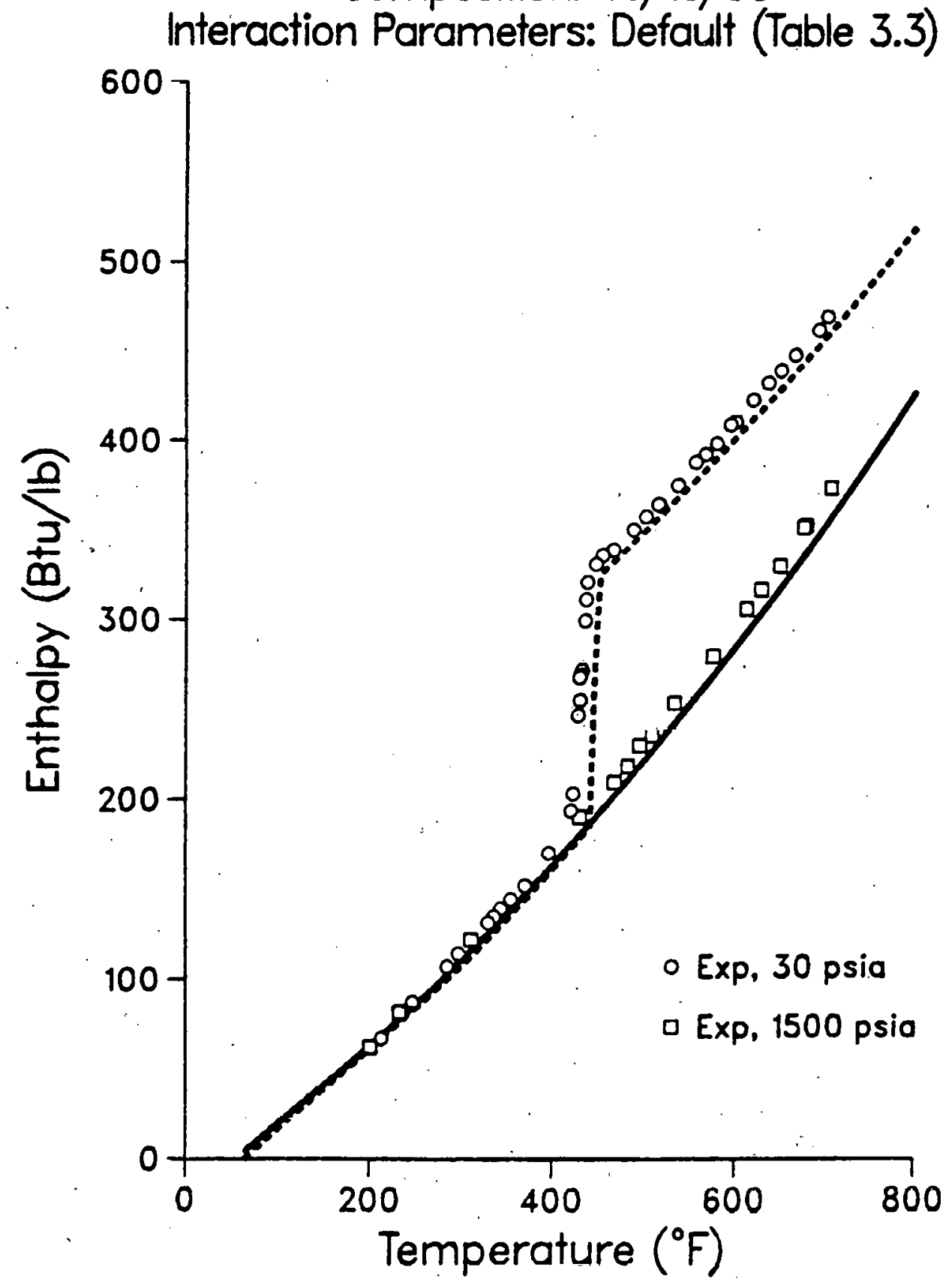


Figure 3.5

Enthalpy of Quinoline/1-Methylnaphthalene/t-Decalin Composition: 20/40/40 Interaction Paramełers: Default (Table 3.3)

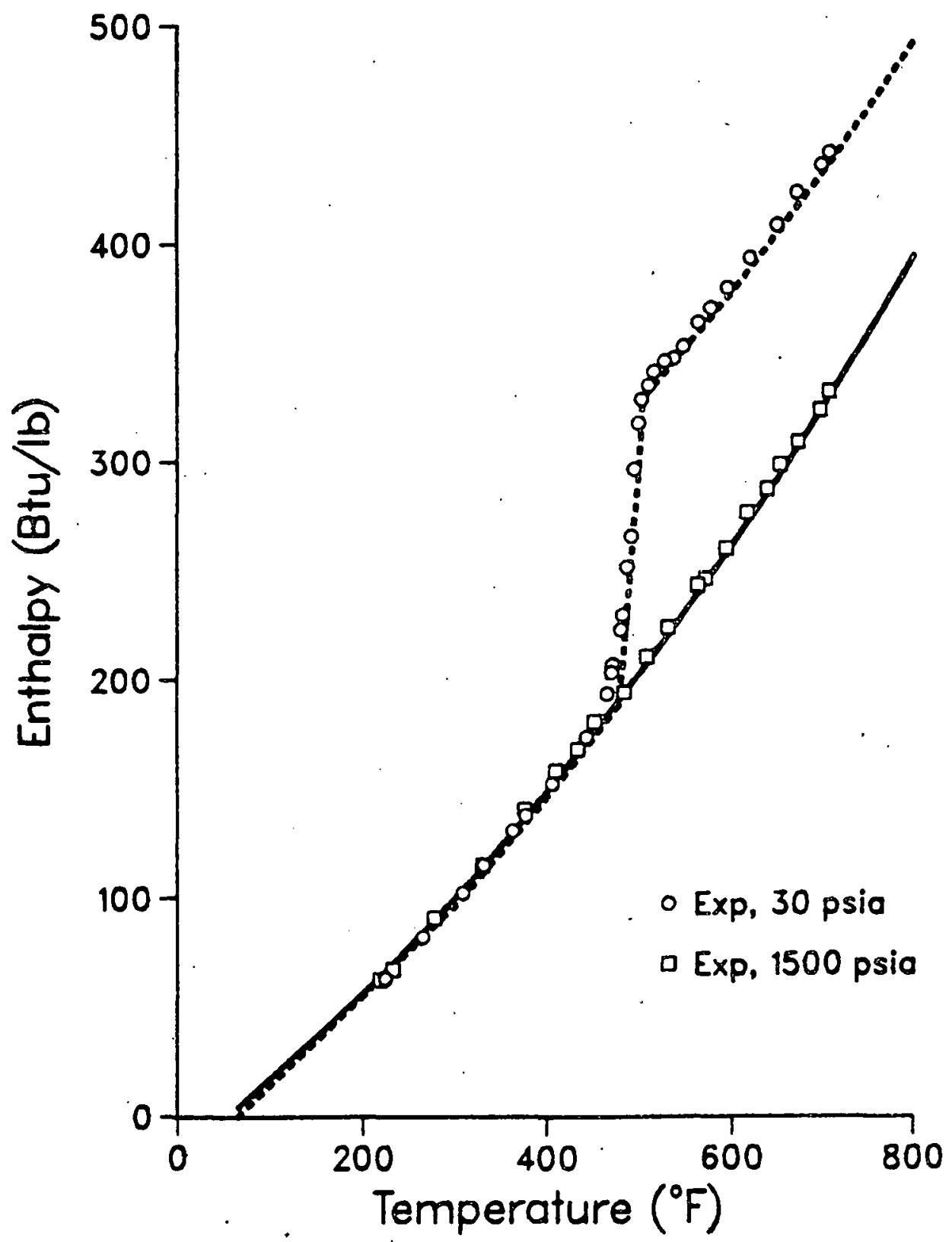


Figure 3.6

Enthalpy of Quinoline/1-Methylnaphthalene/ $t-$ Decalin Composition: 40/10/50

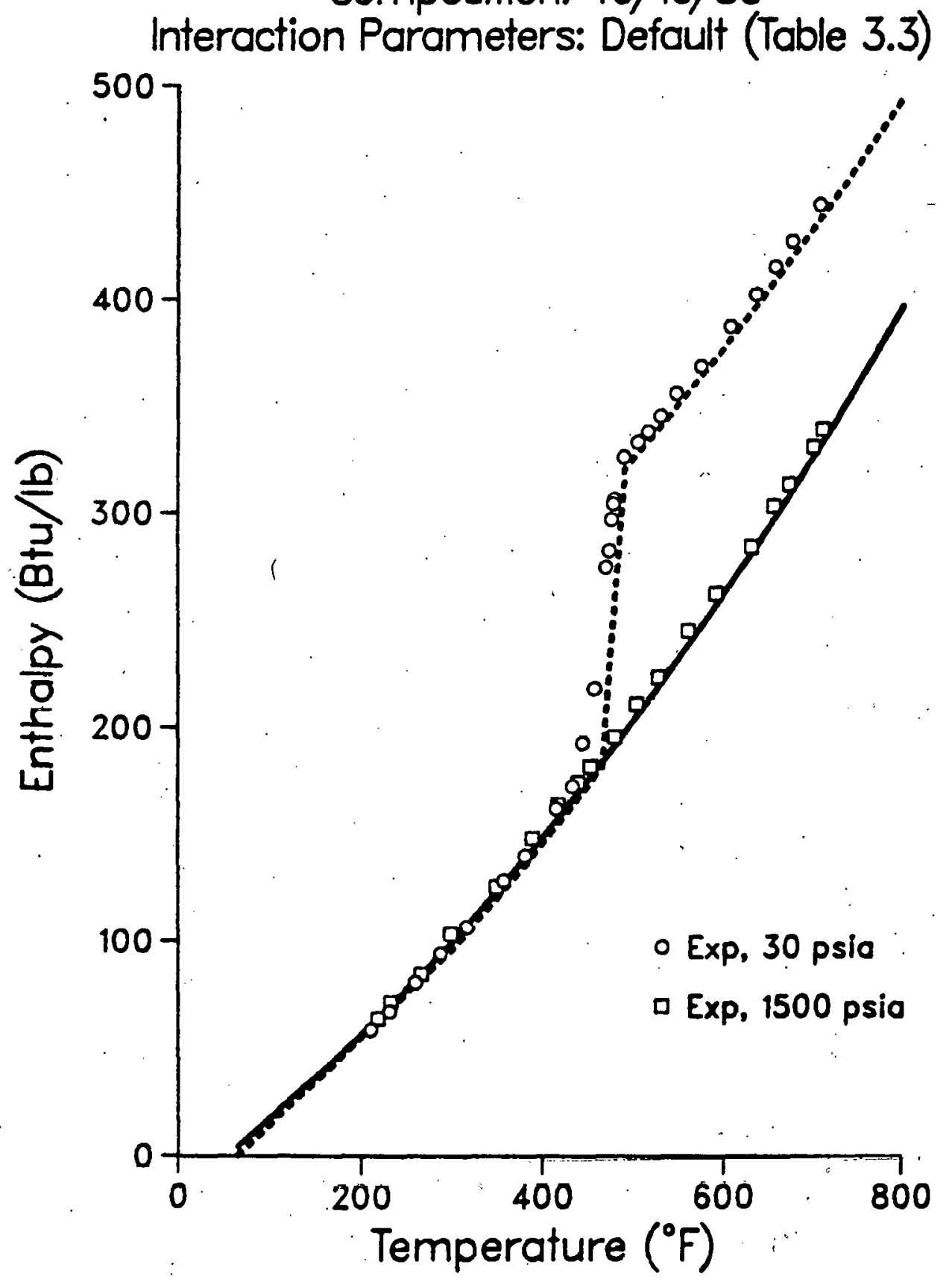


Figure 3.7

Enthalpy of $m$-Cresol/Quinoline/1-Methylnaphthalene/t-Decalin Composition: 30/15/40/15 Interaction Parameters: Default (Table 3.3)

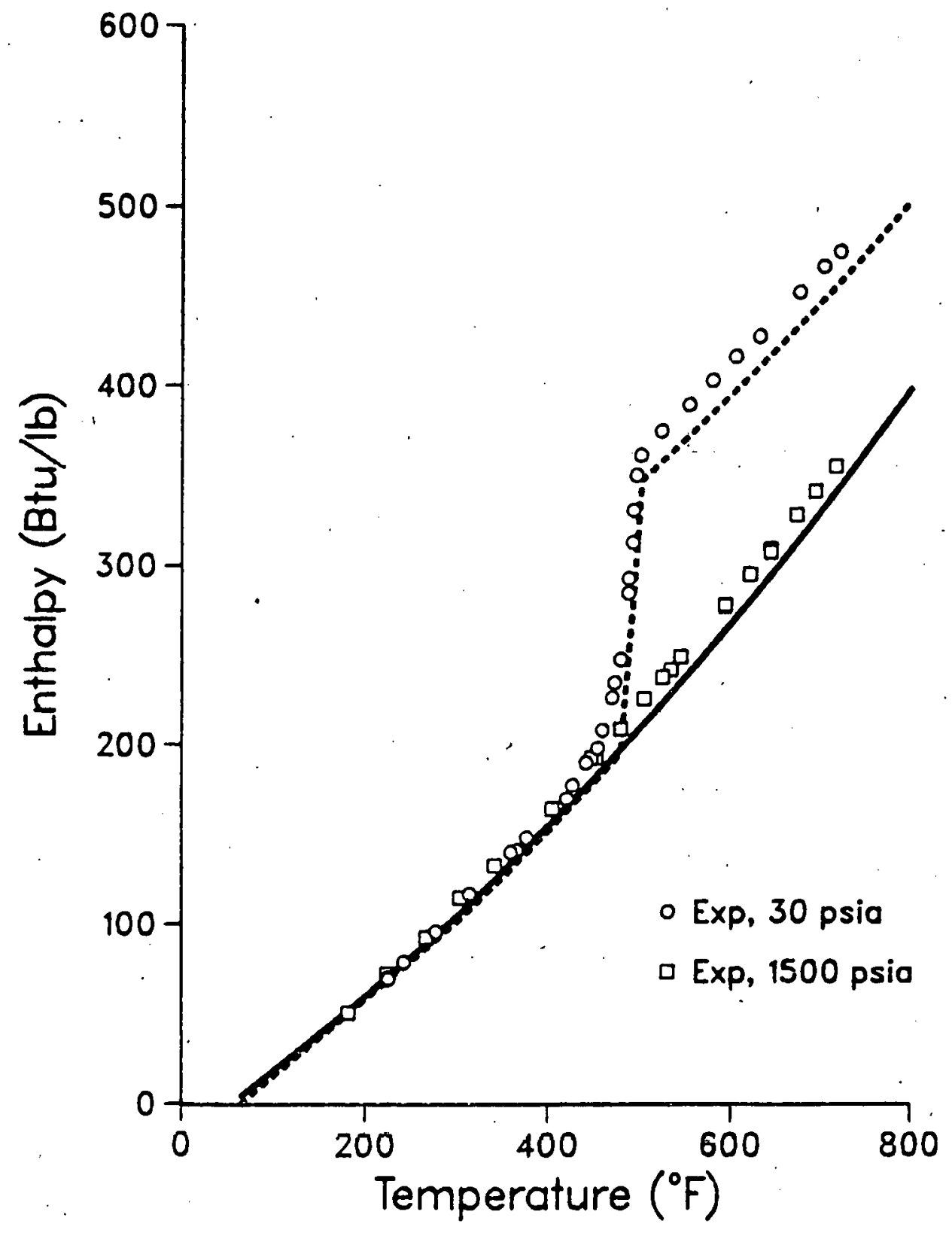


Figure 3.8

Enthalpy of $m$-Cresol/Quinoline/1-Methylnaphthalene/t-Decalin Composition: 15/30/40/15 Interaction Parameters: Default (Table 3.3)

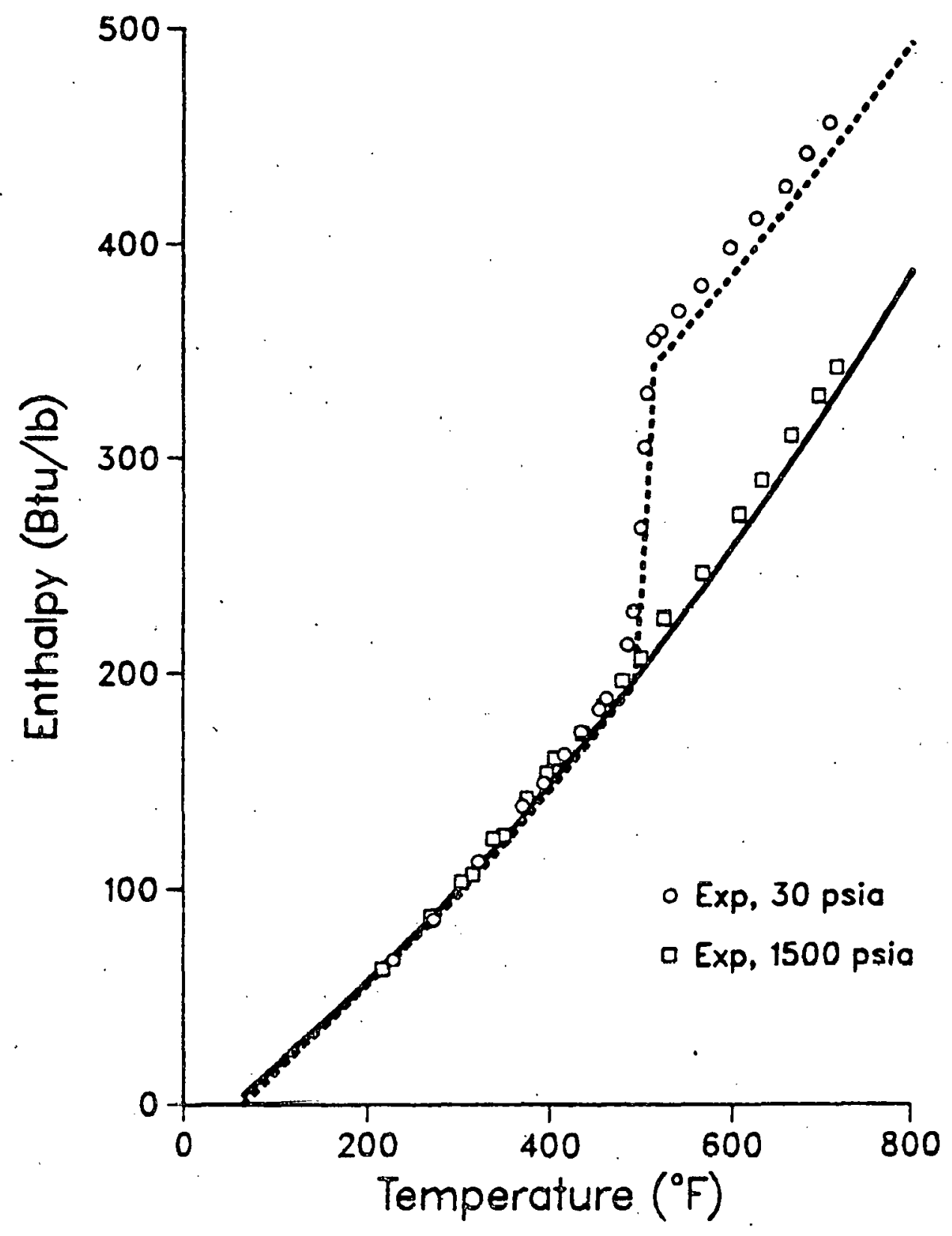


Figure 3.9

Enthalpy of $m$-Cresol/Quinoline/1-Methylnaphthalene/t-Decalin

Composition: $20 / 20 / 40 / 20$

Interaction Parameters: Default (Table 3.3)

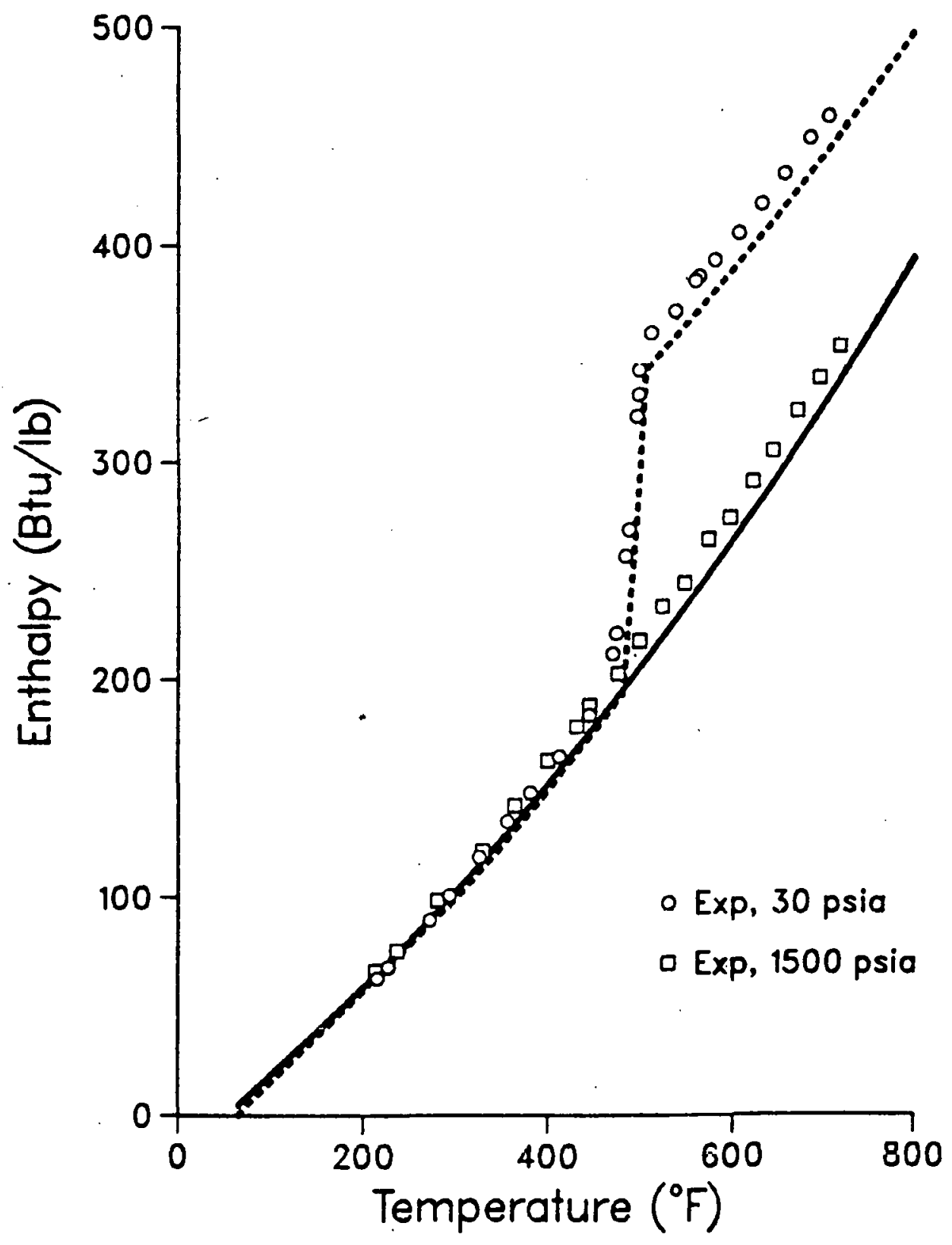


Figure 3.10

Enthalpy of $\mathrm{m}$-Cresol/1-Methylnaphthalene/t-Decalin Composition: 60.33/29.33/10.34

Interaction Parameters: Enthalpy (Table 3.3)

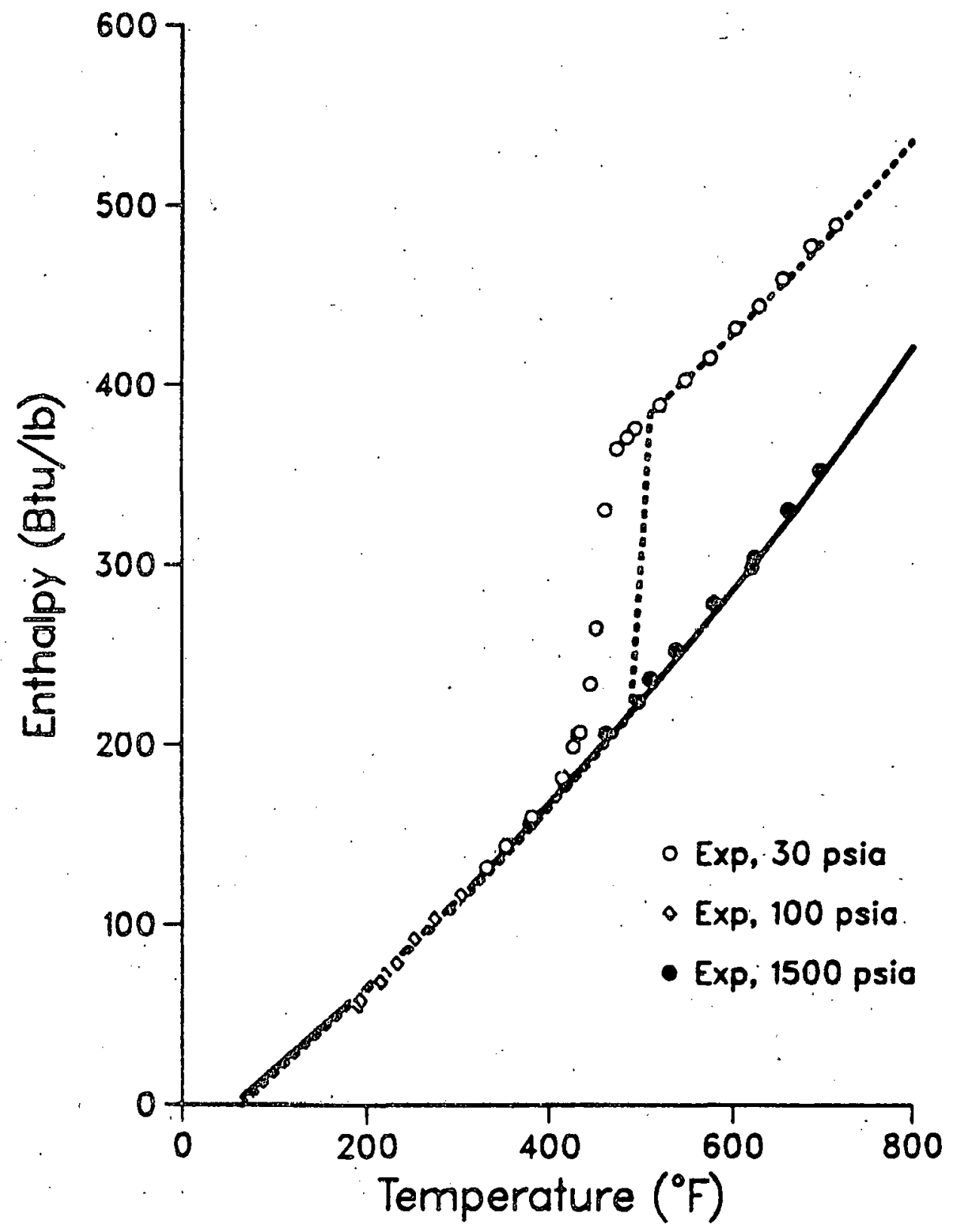


Figure 3.11

Enthalpy of Quinoline/1-Methylnaphthalene/t-Decalin Composition: 60/30/10 Interaction Parameters: Enthalpy (Table 3.3)

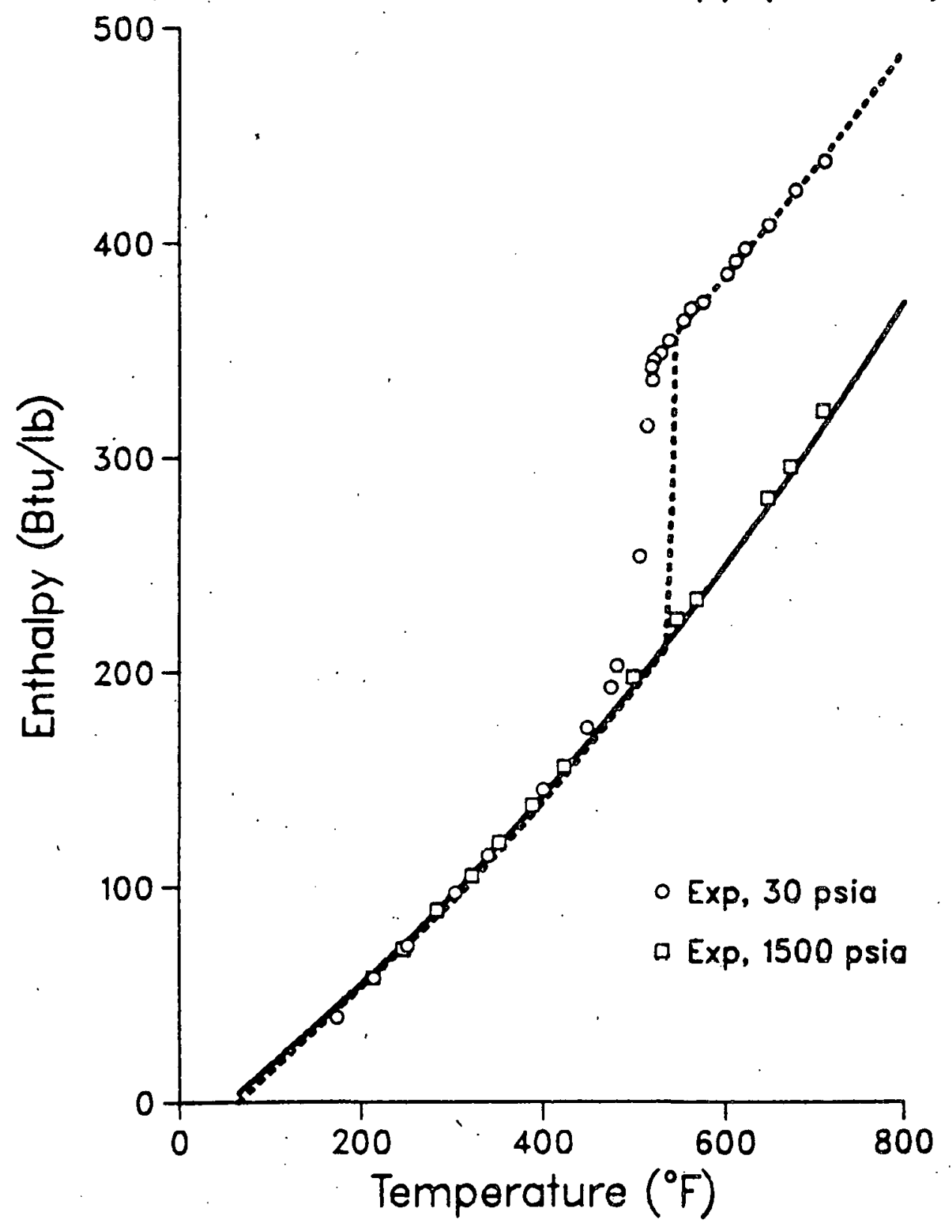


Figure 3.12

Enthalpy of $m$-Cresol/Quinoline/1-Methylnaphthalene/t-Decalin Composition: $20 / 20 / 40 / 20$ Interaction Parameters: Enthalpy (Table 3.3)

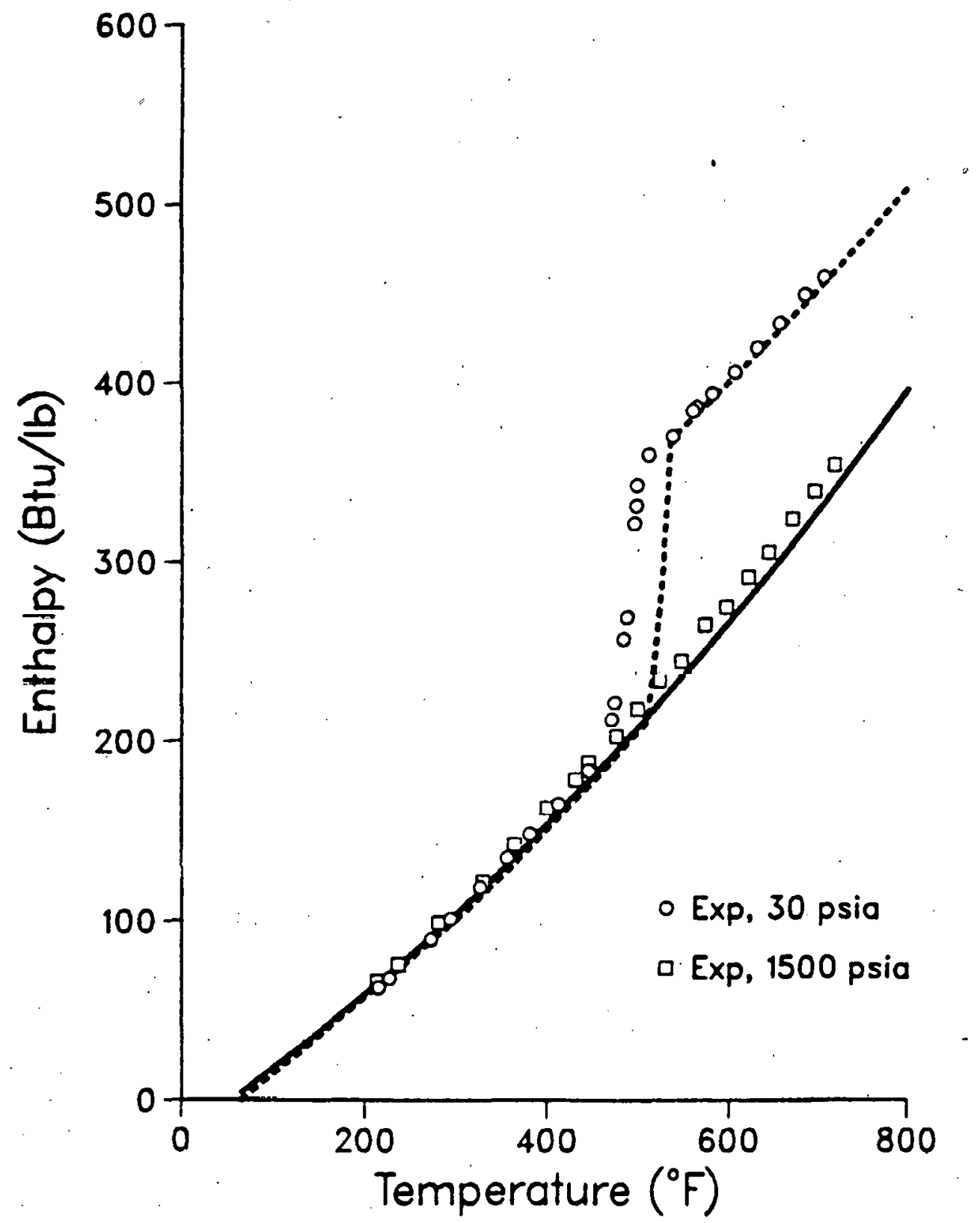




\section{Figure 3.13}

Enthalpy of $m$-Cresol/ 1 -Methylnaphthalene/t-Decalin Composition: $60.33 / 29.33 / 10.34$ Interaction Parameters: VLE (Table 3.3)

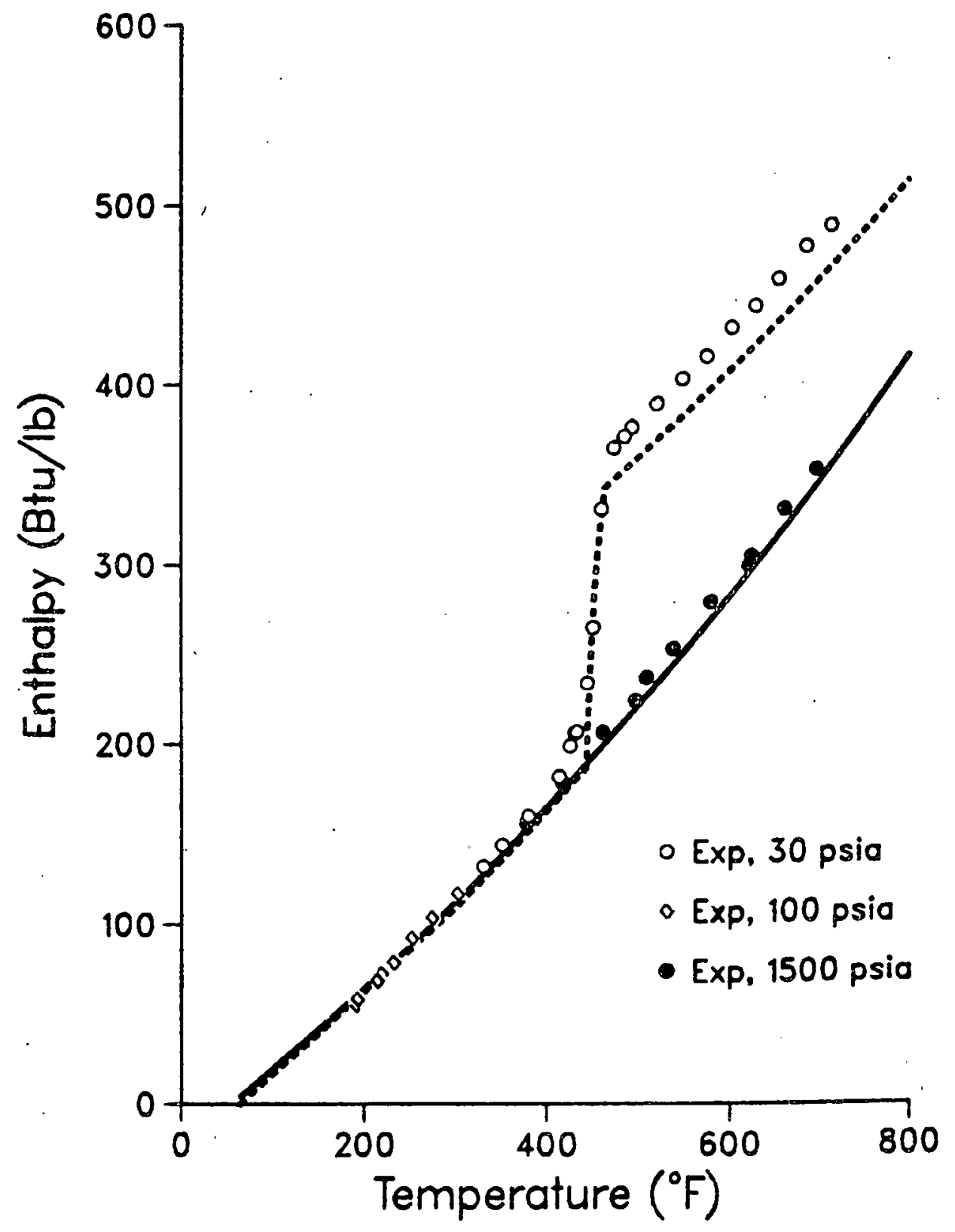


Figure 3.14

Enthalpy of Quinoline/1-Methylnaphthalene/t-Decalin Composition: 60/30/10 Interaction Parameters: VLE (Table 3.3)

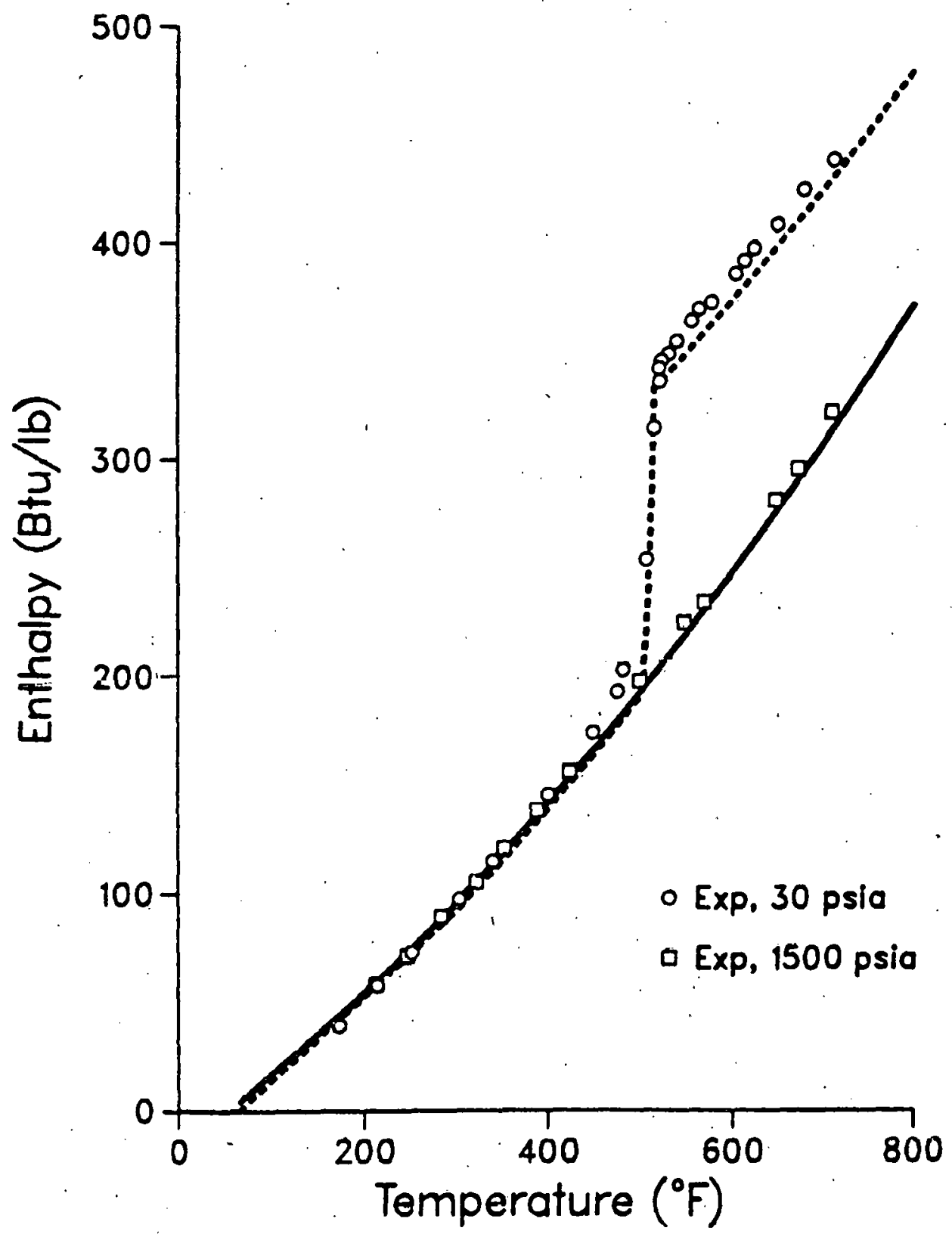


Figure 3.15

Enthalpy of $\mathrm{m}$-Cresol/Quinoline/1-Methy/naphthalene/t-Decalin Composition: $20 / 20 / 40 / 20$ Interaction Parameters: VLE (Table 3.3)

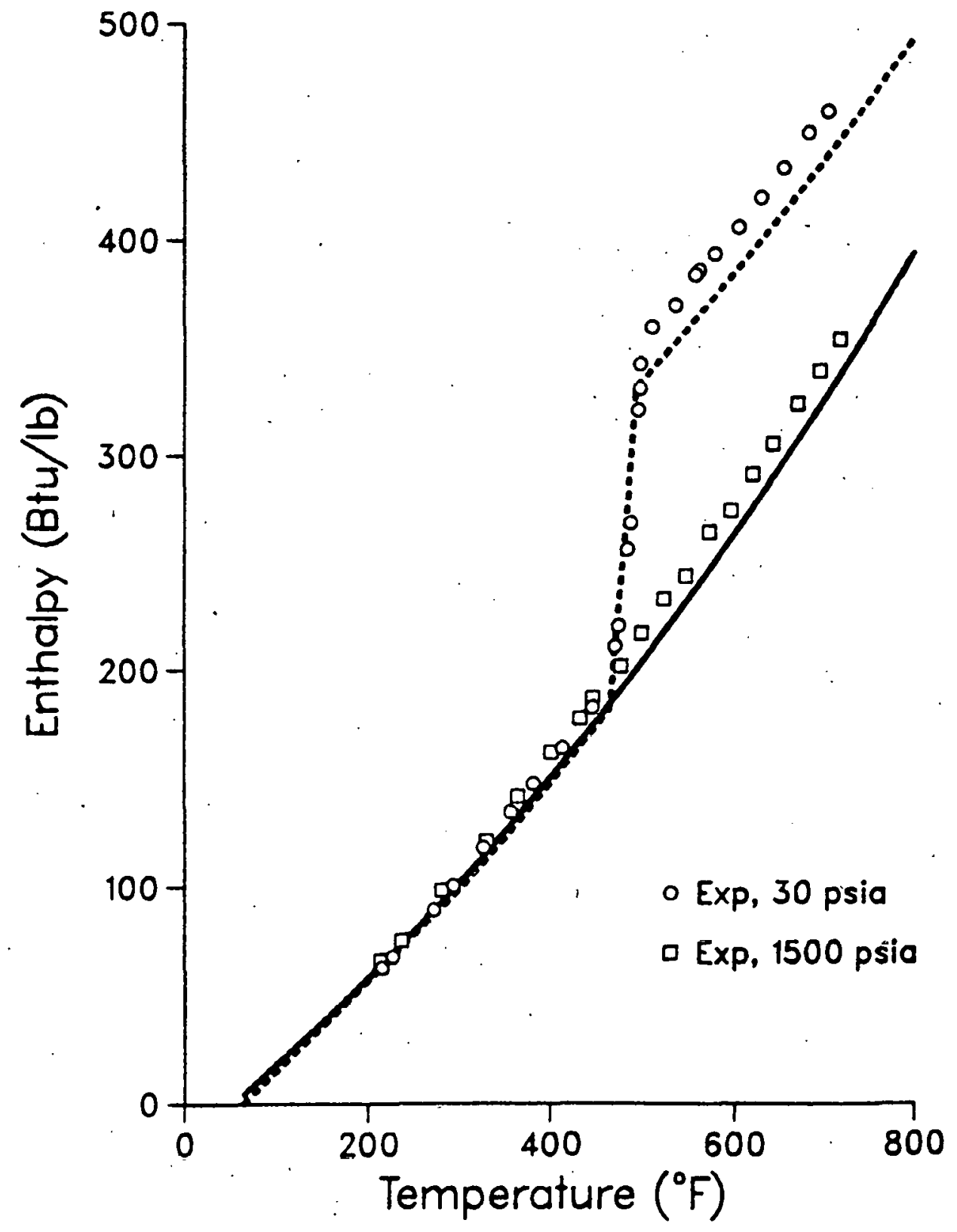


Figure 4.1

Liquid Heat Capacity of Cut $600-650^{\circ} \mathrm{F}$ at 15 psia Peng-Róbinson Vs. Experimental Data

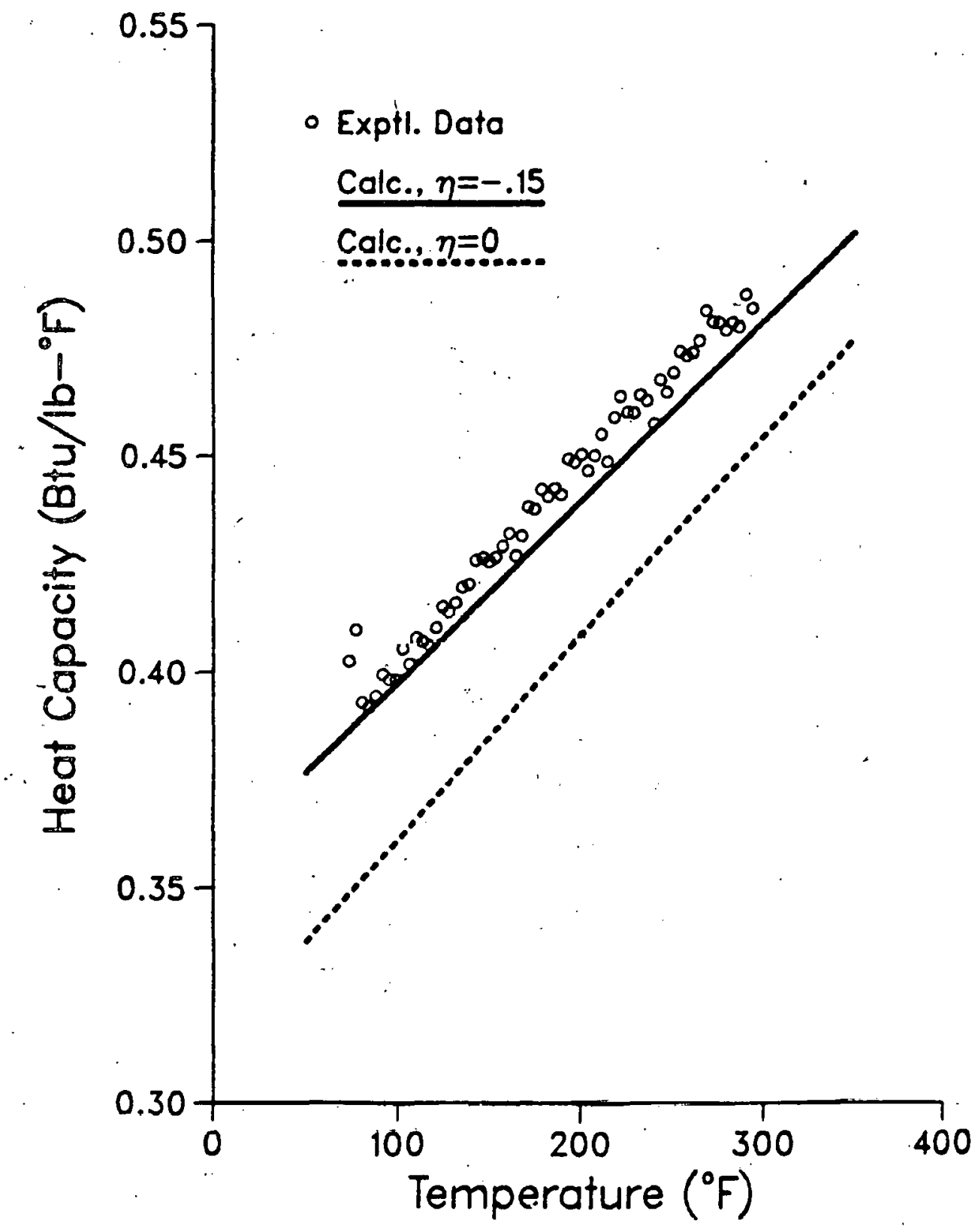


Figure 4.2

Liquid Heat Capacity of Cut $700-750^{\circ} \mathrm{F}$ at 15 psia Peng-Robinson Vs. Experimental Data

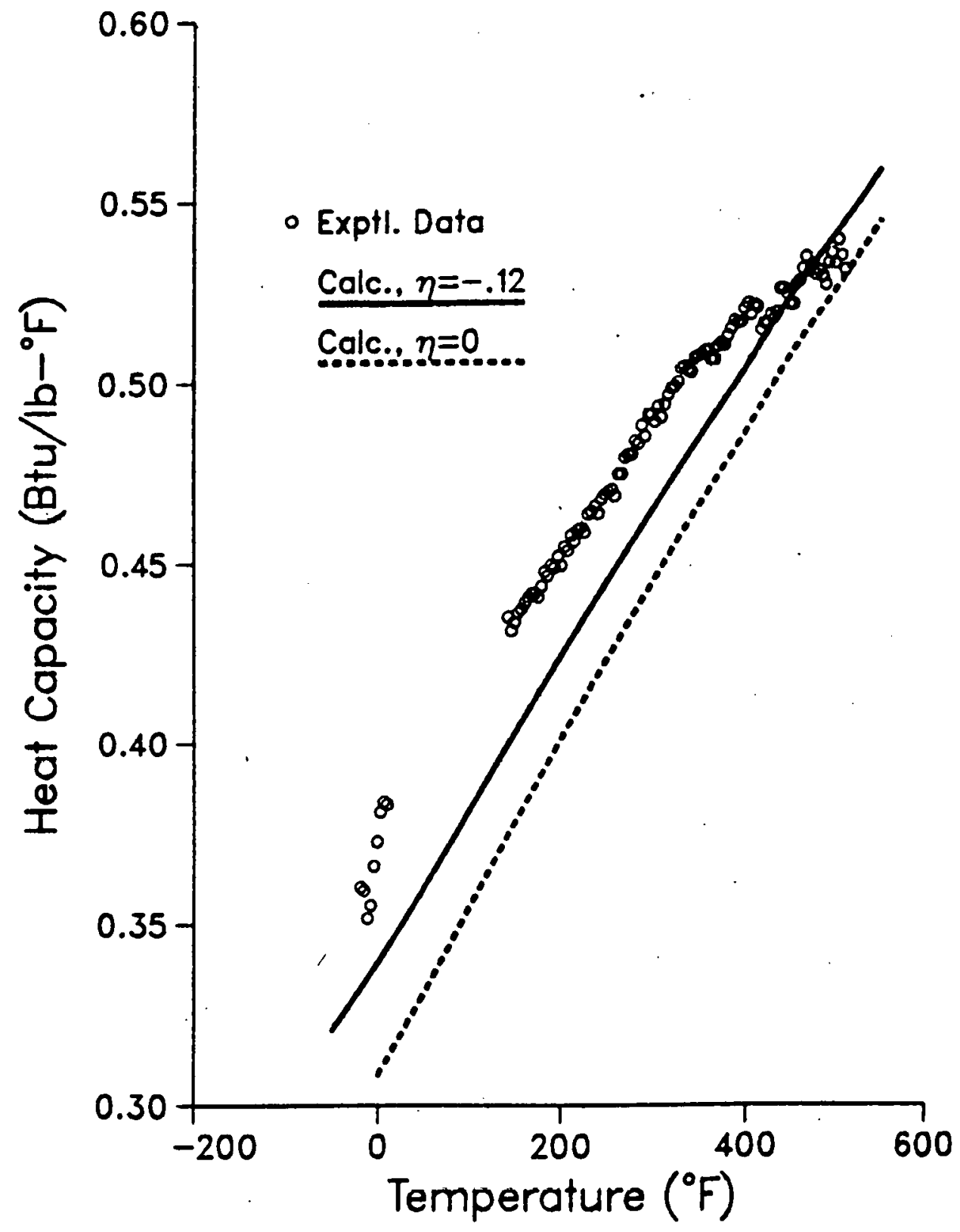


Figure 4.3

Liquid Heat Capacity of Cut $700-750^{\circ} \mathrm{F}$ at 15 psia Peng-Robinson Vs. Experimental Data (CSM and Gulf)

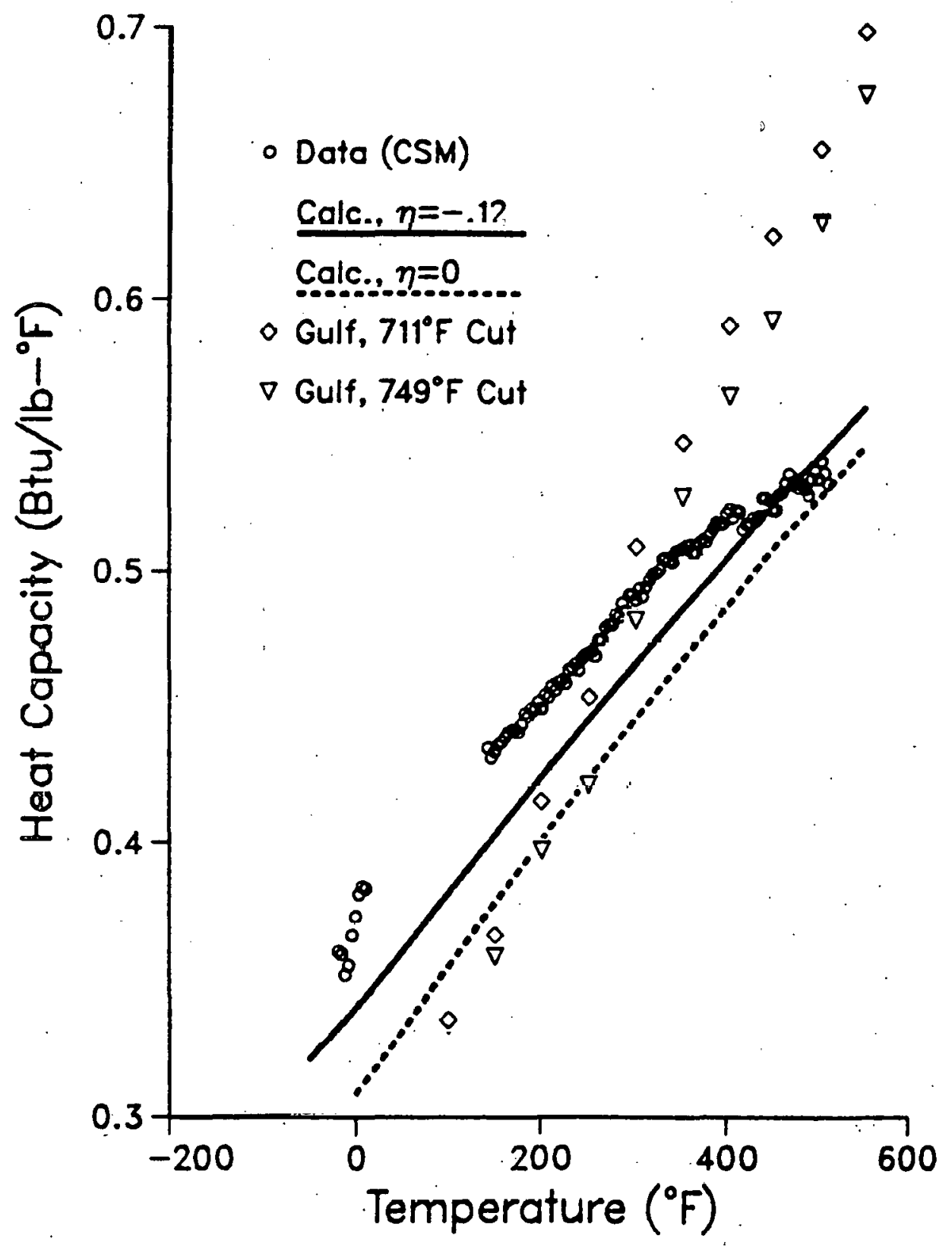


Figure 4.4

Boiling -Point Distribution of SRC-I Coal Liquids

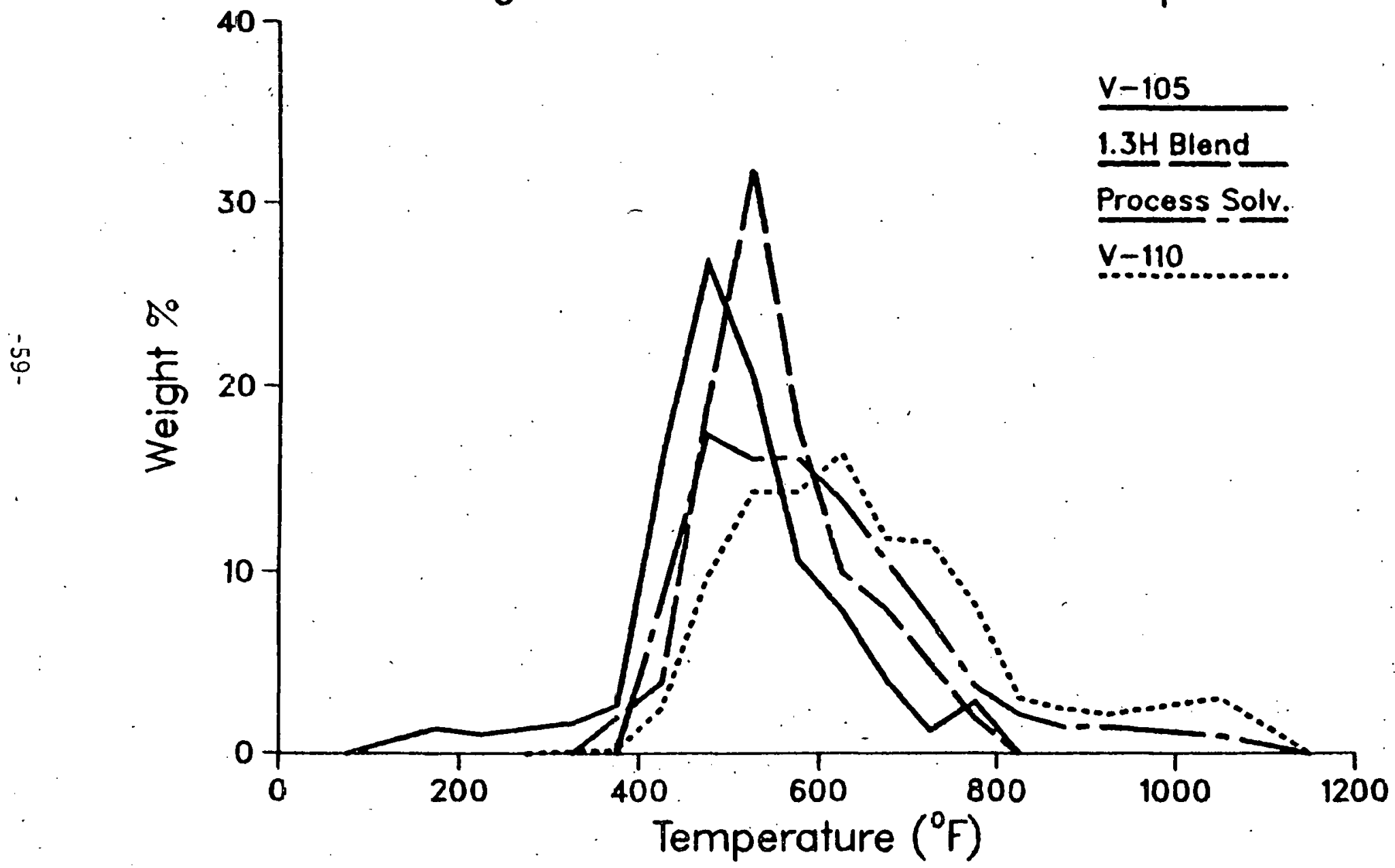


Figure 4.5

Liquid Heat Capacity of V-110 Bottoms at 15 psia Peng-Robinson Vs. Experimental Data

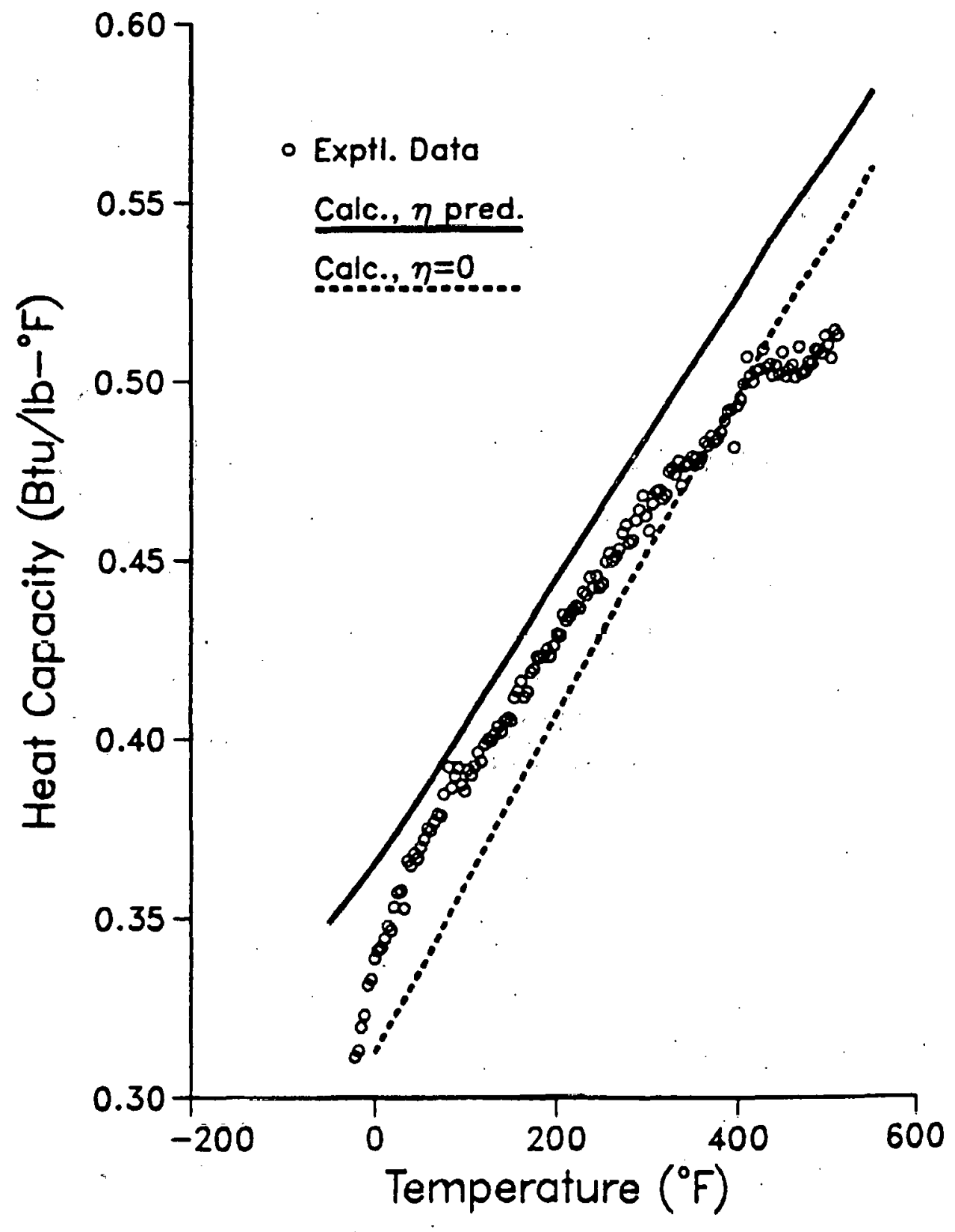


Figure A-1

Specific Gravity Assumed for SRC-1 Pseudocomponents

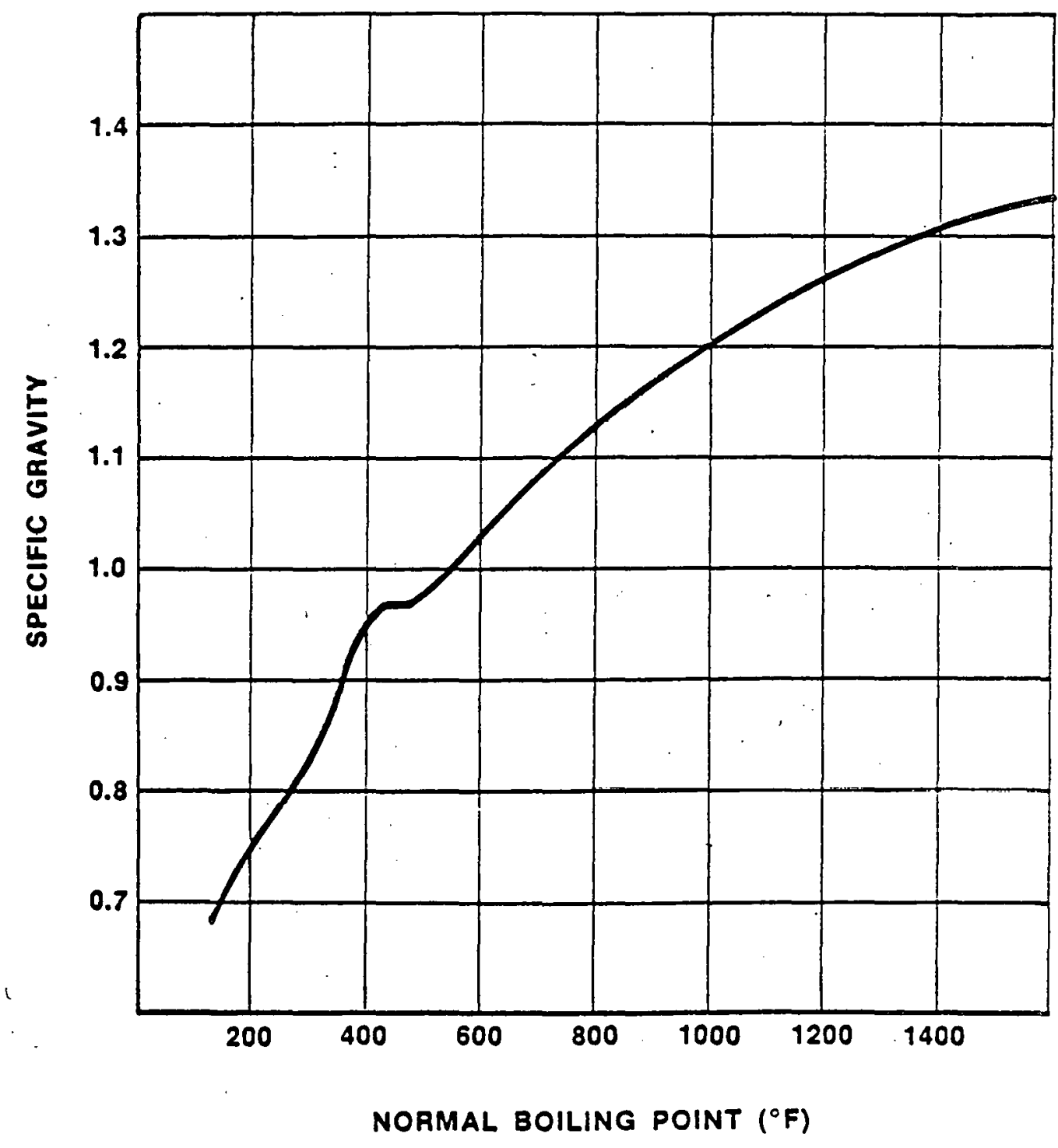


Figure A-2

Correlation of Polar Parameler " Ior SAC-I Pseudocomponents

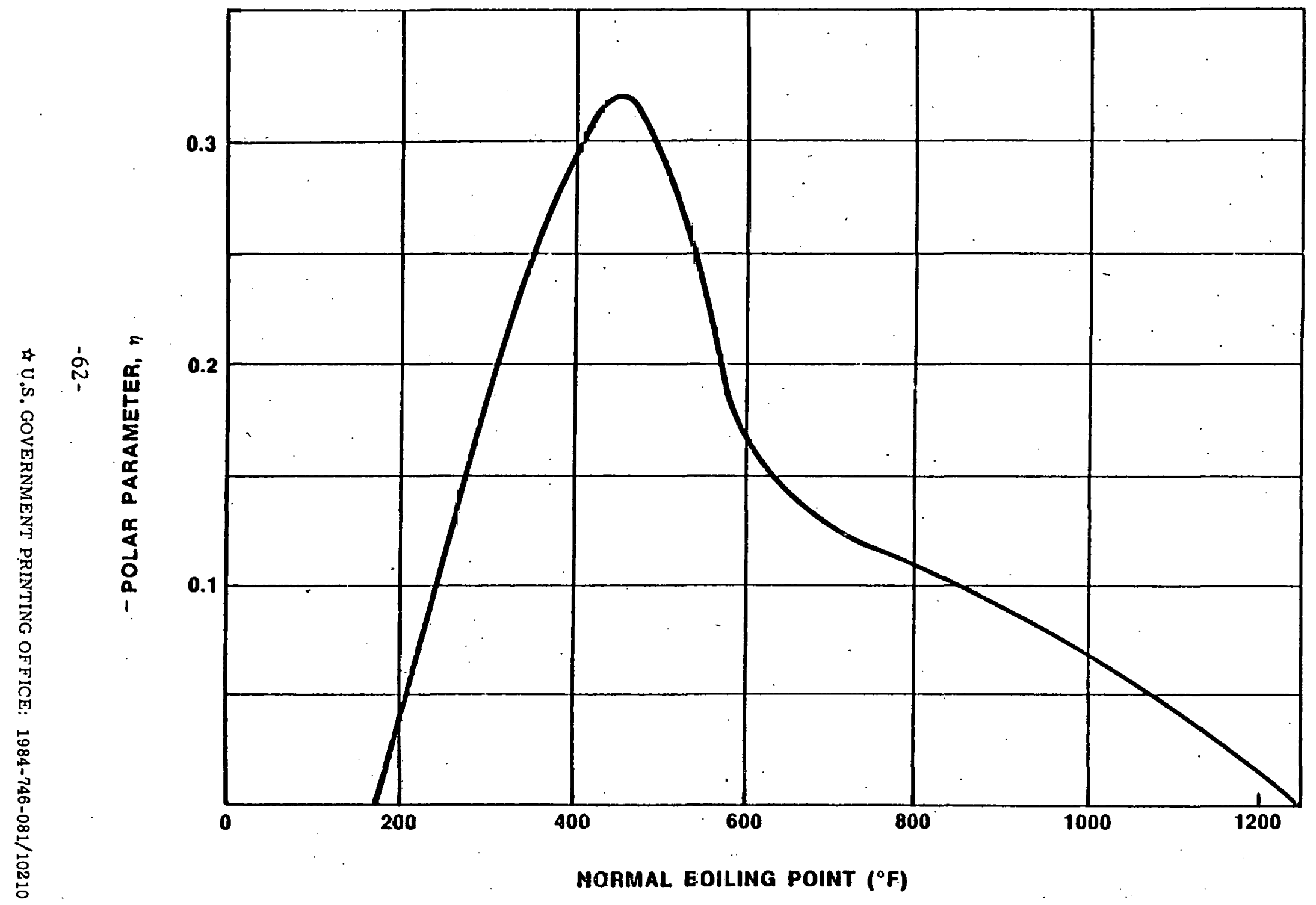


